
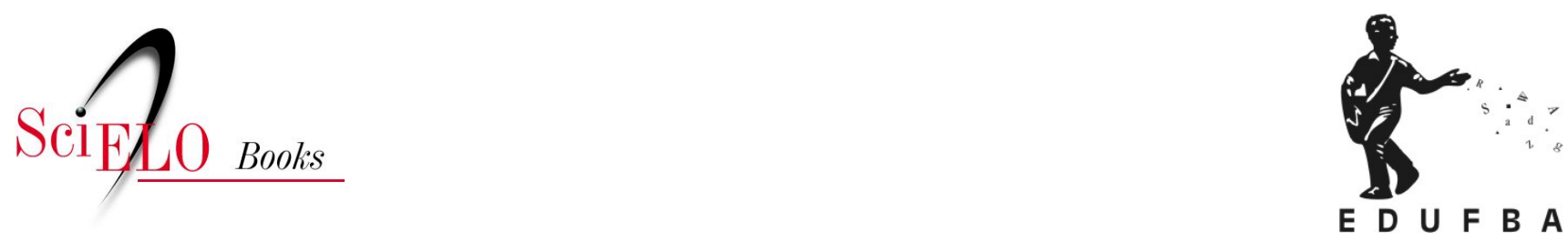

\title{
Formação do professor
}

a docência universitária em busca de legitimidade

\author{
Sandra Regina Soares \\ Maria Isabel da Cunha
}

SOARES, SR., and CUNHA, MI. Formação do professor: a docência universitária em busca de legitimidade [online]. Salvador: EDUFBA, 2010. 134 p. ISBN 978-85-232-1198-1. Available from

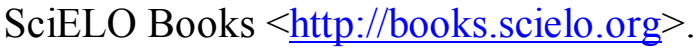

\section{(2)(1)(2)}

All the contents of this chapter, except where otherwise noted, is licensed under a Creative Commons Attribution-Non Commercial-ShareAlike 3.0 Unported.

Todo o conteúdo deste capítulo, exceto quando houver ressalva, é publicado sob a licença Creative Commons Atribuição Uso Não Comercial - Partilha nos Mesmos Termos 3.0 Não adaptada.

Todo el contenido de este capítulo, excepto donde se indique lo contrario, está bajo licencia de la licencia Creative Commons Reconocimento-NoComercial-CompartirIgual 3.0 Unported. 


\section{Formação do professor}

a docência universitária em busca de legitimidade 


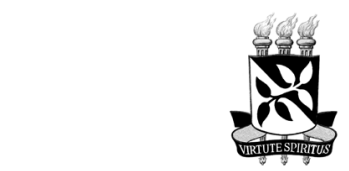

UNIVERSIDADE FEDERAL DA BAHIA

Reitor

Naomar Monteiro de Almeida Filho

Vice-Reitor

Francisco José Gomes Mesquita

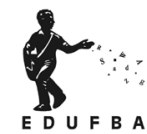 \\ EDITORA DA UNIVERSIDADE FEDERAL DA BAHIA \\ Diretora \\ Flávia Goullart Mota Garcia Rosa \\ Conselho Editorial \\ Titulares \\ Ângelo Szaniecki Perret Serpa, Alberto Brum Novaes, \\ Caiuby Alves da Costa, Charbel Ninõ El-Hani, \\ Dante Eustachio Lucchesi Ramacciotti, \\ José Teixeira Cavalcante Filho, Maria Vidal de Negreiros Camargo \\ Suplentes \\ Antônio Fernando Guerreiro de Freitas, \\ Evelina de Carvalho Sá Hoisel, Cleise Furtado Mendes
}

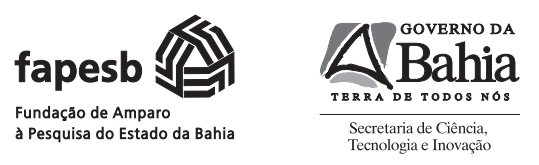


Sandra Regina Soares

Maria Isabel da Cunha

\section{Formação do professor} a docência universitária em busca de legitimidade

Salvador

EDUFBA - 2010 
(C)2010, by Autores.

Direitos de edição cedidos à EDUFBA. Feito o depósito legal.

\author{
Projeto Gráfico, Editoração Eletrônica e Capa \\ Alana Gonçalves de Carvalho Martins \\ Revisão \\ Zélia Chequer \\ Normalização \\ Tatiana Campos da Hora
}

Sistema de Bibliotecas - UFBA

Soares, Sandra Regina.

Formação do professor : a docência universitária em busca de legitimidade /

Sandra Regina Soares, Maria Isabel da Cunha. - Salvador : EDUFBA, 2010.

$134 \mathrm{p}$.

ISBN 978-85-232-0677-2

1. Professores universitários - Formação. 2. Programas de Pós-graduação Educação. 3. Pós-graduação. I. Cunha, Maria Isabel da. II.Título.

Editora filiada à:

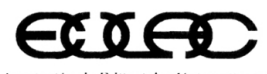

Asoclación de Editorlates Universitarias de America Latina y el Caribe

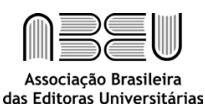

$\mathrm{CBaL}$

das Editoras Universitárias

\title{
EDUFBA
}

Rua Barão de Jeremoabo, s/n, Campus de Ondina, 40170-115,

Salvador-BA, Brasil

Tel/fax: (71) 3283-6164

www.edufba.ufba.br I edufba@ufba.br 


\section{Sumário}

Apresentação 7

\section{Capítulo 1}

Contextualização do estudo

Perspectiva metodológica 19

\section{Capítulo 2}

A docência universitária e a formação para seu exercício 23

A docência como atividade complexa 24

A formação do professor 30

A formação do professor universitário 33

Desenvolvimento profissional de professores 35

\section{Capítulo 3}

A pós-graduação e a formação de professores no contexto institucional brasileiro 41

A pós-graduação em educação e a formação do docente universitário 50 Os programas de pós-graduação em educação objetos do estudo 52

\section{Capítulo 4}

Programas de pós-graduação em educação e a formação de professor universitário na perspectiva dos egressos 59

As motivações dos egressos em relação aos programas de pós-graduação em educação 59

Principais aprendizagens nos programas e repercussão na atuação docente na educação superior dos egressos

61

A formação do professor universitário na perspectiva dos egressos

64

A regulamentação da docência universitária 71 


\section{Capítulo 5}

Programas de pós-graduação em educação: o lugar da formação do professor universitário e os projetos pedagógicos em ação 79

Objetivos da pós-graduação stricto sensu 80

O papel específico da pós-graduação em educação 81

A contribuição do programa de educação para a formação do professor universitário 83

A concepção de docência universitária 91

O lugar da formação do docente universitário 103

A avaliação da CAPES frente à dimensão pedagógica

como função da pós-graduação 110

\section{Capítulo 6}

Reflexões e dilemas sobre a formação do docente da educação superior 117

Referências 129 


\section{Apresentação}

O livro Formação do professor: a docência universitária em busca de legitimidade decorre do estudo intitulado $O$ espaço de formação da docência universitária nos programas de pós-graduação em educação de duas universidades públicas da Bahia, desenvolvido no âmbito da pesquisa interinstitucional Trajetórias e lugares de formação da docência universitária: da perspectiva individual ao espaço institucional a ser realizada, que pretendeu mapear as alternativas existentes de formação do professor universitário, especialmente as que acontecem em espaços formais, ainda que não de maneira universalizada, e, muitas vezes, sem condição de acompanhamento, reflexão e visibilidade de seus resultados. O presente estudo dedicou atenção ao espaço da pós-graduação stricto sensu em educação, que crescentemente acolhe, como pós-graduandos, professores da educação superior com formação em áreas diversas.

Objetivamos, com este trabalho, conhecer as motivações políticas e institucionais, formatos, bases epistemológicas e significados dos programas de pós-graduação em educação das instituições, no que tange à formação da docência universitária, tomando como base os depoimentos de egressos e de coordenadores desses programas.

O livro é composto de seis capítulos. O Capítulo 1, Contextualização do estudo, situa importantes elementos do contexto social, político, econômico e epistemológico que concorrem para a emergência de questionamentos relativos ao papel da educação superior e, por conseguinte, da docência universitária. Fica evidente que o modelo de docente universitário porta-voz de um saber dogmatizado, capaz de transferir, pelo dom da oratória, em aulas magistrais, seus saberes profissionais, não mais atende as necessidades da sociedade contemporânea, o que coloca na ordem do dia o debate sobre a formação dos docentes desse nível de ensino. Nesse cenário, amplia-se a busca pela titulação em cursos de pós-graduação, principalmente, com a Lei 9.394/96, 
que estabelece o limite mínimo de um terço do corpo docente das instituições universitárias com titulação acadêmica de mestrado ou doutorado. Destaca-se o expressivo número de professores da educação superior, de todas as áreas, admitido pelos programas de pós-graduação stricto sensu em educação. Esses elementos deram origem a uma pesquisa de caráter interinstitucional, cujos objetivos, questões norteadoras e percurso metodológico são, também, apresentados nesse capítulo.

O Capítulo 2, A docência universitária e a formação para seu exercício, parte do resgate da etimologia da palavra docência, originada do termo latino docere, que significa ensinar, que se complementa com discere, que significa aprender. Fundamenta a compreensão de docência como atividade complexa, tendo em conta que seu exercício envolve condições singulares e exige uma multiplicidade de saberes, competências e atitudes que precisam ser apropriados e compreendidos em suas relações. Essa complexidade aponta para o desafio da formação do docente universitário e, nesse sentido, discutem-se os conceitos de formação e de desenvolvimento profissional do docente universitário.

O Capítulo 3, A pós-graduação e a formação de professores no contexto institucional brasileiro, que tem como foco a formação do docente universitário, analisa, no primeiro momento, os principais documentos referentes à pós-graduação stricto sensu no Brasil, a saber, o Parecer 977/65, que institucionaliza esse sistema de ensino, define suas finalidades e sua estrutura, o Parecer 77/69, que define as normas de credenciamento dos cursos de pós-graduação, em consonância com o Parecer 977/65, e os Planos Nacionais de PósGraduação (PNPGs). No segundo momento, apresenta as análises do regimento de cada um dos dois programas de pós-graduação em educação objetos do estudo, documento que define os objetivos e a estrutura dos programas. A análise desse conjunto de documentos evidencia que a formação do docente universitário, em especial a formação pedagógica, não faz parte das intenções formais desse nível de ensino nem desses programas de educação. 
O Capítulo 4, Programas de pós-graduação em educação e a formação de professor universitário na perspectiva dos egressos ${ }_{L}$ apresenta e discute os dados obtidos junto aos egressos dos dois programas de pós-graduação stricto sensu em educação, destacando as motivações para a escolha do programa, as principais aprendizagens e repercussão na atuação docente dos egressos, a formação do professor universitário, a regulamentação da docência universitária. Conclui com a constatação de que a experiência vivenciada pelos pós-graduandos, baseada na investigação e na inter-relação entre teoria e prática, contribuiu para ressignificar, em algum nível, as suas práticas educativas, mas a complexidade da docência universitária segue despercebida.

O Capítulo 5, Programas de pós-graduação em educação: o lugar da formação do professor universitário e os projetos pedagógicos em ação, discute os resultados que emanam dos depoimentos dos coordenadores dos programas de pós-graduação em estudo, concernentes aos objetivos da pós-graduação stricto sensu, ao papel específico da pós-graduação em educação, à contribuição do programa de educação para a formação do professor universitário, à concepção de docência universitária, ao lugar da formação do docente universitário e à avaliação da Coordenação de Aperfeiçoamento de Pessoal de Nível Superior (CAPES) frente à dimensão pedagógica, como função da pós-graduação. Na conclusão, evidencia que os programas de pós-graduação em educação, objeto deste estudo, têm como tarefa central a formação de pesquisador, concomitantemente, com o silenciamento sobre a formação pedagógica e didática de novas gerações de mestres e doutores.

O Capítulo 6, Reflexões e dilemas sobre a formação do docente da educação superior, propõe-se a fazer um cotejamento entre os dados que emanam dos depoimentos dos egressos e dos coordenadores dos programas de pós-graduação stricto sensu em estudo e sua contextualização no cenário institucional que orienta as práticas desse nível de ensino. Esse esforço reflexivo permitiu concluir que a docência universitária e sua formação não faziam parte, 
essencialmente, das preocupações desses atores, que se centravam na formação para pesquisa e na formação do pesquisador, em sintonia com os critérios de avaliação instituídos. A despeito de algumas repercussões nas suas práticas educativas como docentes da educação superior, mencionadas pelos egressos, a formação da docência universitária, em especial a formação pedagógica, resta, no essencial, ausente.

Esperamos com esta obra contribuir para visibilidade e fortalecimento da pedagogia universitária, campo de pesquisa, prática e formação, que se interessa pelo processo de ensino e aprendizagem, pelas condições de exercício e saberes da docência e pelas teorias e práticas de formação de professores e estudantes da educação superior. 


\section{Capítulo 1}





\section{Contextualização do estudo}

A busca da melhoria da qualidade da atuação do professor universitário há muito vem sendo objeto de iniciativas e de estudos esparsos no interior das próprias universidades, porém a discussão mais sistemática sobre a formação dos professores da educação superior emerge com mais força, no cenário internacional, a partir da década de 80 do século XX. Insere-se num contexto, simultaneamente, de expansão e de questionamentos relativos ao papel da educação superior e, por conseguinte, da docência universitária.

O modelo de docente universitário porta-voz de um saber dogmatizado, capaz de transferir, pelo dom da oratória, em aulas magistrais, seus saberes profissionais, não mais atende as necessidades da sociedade contemporânea. Essa perspectiva, baseada na erudição, parece ainda predominar, exigindo, fundamentalmente, o domínio de conteúdos específicos da área de conhecimento, sem a preocupação de conhecer os estudantes e sua cultura, a fim de possibilitar-lhes uma aprendizagem significativa e uma formação profissional voltada para o enfrentamento crítico dos problemas da sociedade. 
Esse modelo remonta às origens da universidade, na Idade Média, mas manteve seus traços essenciais quando a universidade abraçou a ciência moderna positivista. Essa concepção de ciência tem como características mais marcantes, para o que nos interessa neste estudo: a negação do caráter racional a todas as formas de conhecimento que não se orientam pelos seus princípios epistemológicos e metodológicos, se configurando, assim, em um "modelo totalitário"; a redução da complexidade, mediante a divisão e classificação dos fenômenos, para, depois, estabelecer relações sistemáticas entre as partes separadas; a natureza causal do conhecimento científico, que visa à formulação de leis e à previsão do comportamento futuro dos fenômenos; a ideia de ordem e de estabilidade do mundo, que se expressa no determinismo mecanicista e, consequentemente, na concepção de conhecimento funcional, mais interessado em dominar e transformar do que em compreender os fenômenos; a neutralidade do cientista; a racionalidade técnica. Em síntese, uma epistemologia que, conforme Santos (2005a, p. 17), "[...] não se questiona no ato de questionar nem aplica a si própria o grau de exigência com que critica."

Esses pressupostos se expressam na prática educativa em que há certo distanciamento entre o professor e os estudantes. Configuram-se pela representação de que o professor é dono do saber racional, científico e válido, enquanto o estudante é visto como destituído de saber ou, no máximo, portador de um saber de segunda categoria. Esse saber se liga ao senso comum, como se fossem conteúdos "objetivos", que apresentam resistência a engajar os sujeitos em contextos concretos e a refletir sobre as questões subjetivas envolvidas nos processos de ensino e aprendizagem. $\mathrm{O}$ paradigma dominante de ciência, entretanto, como afirma Santos (2005a), atravessa uma profunda e irreversível crise, que resulta do aprofundamento do conhecimento que ele permitiu criar, evidenciando, assim, suas próprias insuficiências e limitações estruturais. A crise desse paradigma, naturalmente, contribui para o questionamento quanto ao modelo de professor chamado tradicional. 
A ampliação das críticas à universidade e à sua função social, historicamente vinculada à formação da elite, assegurando-lhe o acesso aos conhecimentos científicos, humanísticos da alta cultura, e a pressão para que ela se ocupe da “[...] produção de padrões culturais médios e de conhecimentos instrumentais, úteis na formação de mão-de-obra qualificada exigida pelo desenvolvimento capitalista [...]" (SANTOS, 2005b, p. 8), são outros fatores que compõem o cenário de questionamentos à docência universitária e colocam, na ordem do dia, a discussão sobre a sua formação.

Diante das críticas e da pressão de que tem sido alvo, a universidade é compelida a uma ação essencialmente instrumental, determinada pela lógica de competitividade, eficácia e produtividade própria da empresa capitalista. As disciplinas da área das humanidades, cuja natureza está voltada para a reflexão, o questionamento filosófico e social, são vistas como dispensáveis. Nesse contexto, as expectativas e condições dos estudantes diversificam e colocam novos desafios para o docente universitário.

Cabe destacar, como mais um elemento desse cenário, a consolidação de novas formas de acumulação do capital, centradas na globalização da economia e na redução do papel do Estado em relação às áreas sociais, cujos serviços são transformados em mercadorias a serem compradas no livre mercado, ao sabor das leis da oferta e da procura. Nessa lógica de acumulação, o Estado-nação, que emergiu com a sociedade capitalista, passa a desempenhar um papel secundário. Em consequência, os instrumentos reconhecidos como importantes para a consolidação dos projetos nacionais, entre eles, a universidade pública, perdem sua relevância e veem os recursos financeiros públicos serem reduzidos. Para justificar esse desinvestimento e visando tornar o ensino superior um mercado internacional rentável, o neoliberalismo busca difundir a ideia de que a única alternativa para a universidade está na criação do mercado universitário (SANTOS, 2005b, p. 16), ou seja, na abertura do ensino superior para o capital e sua transformação em mercado competitivo. 
Esse mercado está em franca expansão. Do início da década de 1980 até meados da década de 1990, floresceu o mercado universitário nacional e, a partir do final da década de 1990, essa expansão orientou-se para sua transnacionalização. (SANTOS, 2005b) A expansão da educação superior por essa via, segundo dados da Organização das Nações Unidas para a Educação, a Ciência e a Cultura (UNESCO), tem se concentrado em cursos que exigem menores investimentos em equipamento, pessoal e funcionamento. Tal fenômeno tem determinado a ampliação, repentina e significativa, do contingente de docentes da educação superior sem a necessária preparação para a docência.

Em sintonia com essa lógica, o Estado, gradativamente, passa do papel de provedor para o papel de supervisor ao realizar a avaliação externa do sistema de educação superior, pública e privada. Esse processo envolve a avaliação das instituições de ensino superior, dos cursos de graduação, dos professores e do desempenho dos estudantes. Sem deixar de reconhecer a responsabilidade do Estado para com o processo de regulação da educação nacional, as políticas avaliativas tenderam a reduzir a responsabilidade estatal com a educação, deixando ao mercado o protagonismo principal. Uma reação a essa política se fez sentir na década atual, especialmente a concebida pelo Sistema Nacional de Avaliação da Educação Superior $\left(\mathrm{SINAES}^{1}\right)$, cuja perspectiva formativa orienta a melhoria do padrão de qualidade das diferentes instituições de ensino superior e tende a repercutir na identidade do professor, contribuindo para a difusão de uma cultura de auto e heteroavaliação, que repercute nas práticas educativas. Essas iniciativas, contudo, são assumidas de maneira paradoxal e até contraditórias, pois exigem um esforço de mudança na cultura acadêmica. Muitas vezes não conseguem alcançar o objetivo previsto, pois convivem com pressões avaliativas de ordem inversa, que concorrem para a intensificação do individualismo, da competição, além da naturalização da lógica do mercado.

${ }^{1}$ Aprovado pela Lei 10.861, de 14 de abril de 2004. (www.inep.gov.br/superior/SINAES) 
O desenvolvimento, sem precedentes, das tecnologias de informação e comunicação também impacta fortemente os processos educativos, na medida em que possibilita, aos estudantes, o acesso às informações por conta própria e de forma mais atrativa, o que desafia os professores do ensino superior a aperfeiçoarem seus métodos de ensinar e a assumirem um papel menos transmissivo. Exige, principalmente, um processo de mediação voltado para facilitar a compreensão crítica dos estudantes acerca da avalanche de informações disponíveis no mercado virtual e dos valores subjacentes.

Os cursos de pós-graduação stricto sensu, desde a sua implantação na década de 1960, se configuram formalmente como responsáveis pela formação do professor da educação superior. Seus currículos, entretanto, enfatizam fundamentalmente a formação do pesquisador e se omitem em relação à formação para a docência. A ampliação da busca dessa titulação por parte dos professores universitários se verificou, principalmente, com a Lei 9.394/96, que estabelece o limite mínimo de um terço do corpo docente das instituições universitárias com titulação acadêmica de mestrado ou doutorado.

Chama a atenção, porém, o expressivo número de professores da educação superior, de todas as áreas, admitidos pelos programas de pós-graduação stricto sensu em educação. Mesmo não sendo essa uma iniciativa estimulada no contexto de suas áreas específicas, muitos quebram a lógica de se especializarem no seu campo disciplinar e procuram uma formação que atenda a especificidade da profissão docente.

Essa constatação provocou curiosidades sobre as razões que favorecem essa escolha. Estariam esses professores em busca de uma contribuição específica da área da educação para a sua atuação como docentes? Que repercussões percebem eles desses estudos na sua formação e prática pedagógica? A pesquisa respondeu aos seus anseios? Que aprendizagens foram mais significativas para a sua condição como profissionais docentes? Os programas 
de pós-graduação em educação incluem em seus projetos um acolhimento especial a esses professores? Reconhecem que os saberes da docência são parte de sua especificidade?

Interessava ao estudo compreender, também, a especificidade dos programas de pós-graduação em educação no conjunto da pós-graduação no Brasil. Assumem-se como um lugar de formação do docente universitário? Como os programas acolhem as expectativas dos estudantes oriundos de diferentes áreas? Que nível de compreensão revelam de sua ação formativa no campo da pedagogia universitária? Reconhecem a sua função formadora da profissionalidade docente?

Em vista de tais indagações, foram definidos critérios de seleção dos participantes: ser egresso de programas de pós-graduação stricto sensu em educação; ter graduação em área distinta da de pedagogia; e atuar na educação superior. Como interlocutores, ainda, foram eleitos os coordenadores de programas de pósgraduação em educação com intuito de obter as informações que interessavam ao estudo.

Com os convites lançados, aceitaram participar deste estudo onze pessoas, entre egressos e coordenadores, dos programas de pós-graduação em educação de duas universidades públicas da Bahia. Os egressos, em número de sete, haviam concluído seus estudos desde o ano 2000. Entre eles, dois realizaram, no mesmo programa, mestrado e doutorado, e cinco, apenas o mestrado. Quatro são egressos da instituição agora denominada como A, e três, da instituição B. Todos os interlocutores são professores de instituições de ensino superior. Três atuam em instituições públicas, e quatro, em instituições privadas. Possuem graduação em comunicação, psicologia, serviço social, música, teologia, sociologia e letras. Seis são do sexo feminino e um, do sexo masculino.

Foram quatro os professores-coordenadores, dois de cada um dos programas em estudo. Exerciam, no momento da pesquisa, ou exerceram, desde o ano 2000, a tarefa de coordenação desses programas. A participação dos coordenadores desses programas 
na pesquisa possibilitou o cotejamento entre as impressões e aprendizagens construídas pelos egressos e as motivações políticas e institucionais, formatos, bases epistemológicas e significados que orientam os programas de pós-graduação em educação das universidades a que pertencem, no que tange à formação da docência universitária.

\section{Perspectiva metodológica}

Considerando que o interesse que movia o estudo era compreender as significações que os participantes da pesquisa atribuíam aos saberes construídos por eles no desenvolvimento dos cursos de mestrado e doutorado, a abordagem qualitativa pareceu ser mais apropriada. Segundo a literatura, essa abordagem visa explorar a realidade de forma mais completa e profunda possível, destacando o significado e a intencionalidade inerentes aos atos, às relações e às estruturas sociais nas quais estão inseridos os seres humanos. (MINAYO, 1994; LÜDKE; ANDRÉ, 1986)

Para compreender o contexto e a complexidade do objeto de estudo, do ponto de vista epistemológico, escolheu-se, como abordagem de pesquisa, o estudo de caso. Os casos em estudo foram os programas de pós-graduação em educação de duas universidades públicas da Bahia. E, como estratégias de coleta de dados, a análise documental e entrevistas semiestruturadas.

Os documentos fontes de análise foram os textos legais que tratam da formação do professor universitário no Brasil, a exemplo do Parecer 977/65 e dos Planos Nacionais de Pós-Graduação, e os documentos que informam, especificamente, sobre as experiências selecionadas, incluindo os regimentos dos programas e os relatórios elucidativos das experiências de formação.

A entrevista semiestruturada se apoiou em dois roteiros - um para os egressos e outro para os coordenadores -, compostos de questões abertas. No caso dos egressos, inicialmente o roteiro foi enviado para preenchimento e reenvio de forma eletrônica. $\mathrm{Na}$ 
sequência, responderam, de forma presencial, a aspectos que não tinham sido suficientemente explorados nas manifestações por escrito, o que possibilitou o aprofundamento de tais aspectos. Quanto aos professores-coordenadores, a entrevista foi exclusivamente presencial.

Os dados obtidos com a entrevista foram tratados por meio da análise de conteúdo do tipo temática, pois, como sinalizam Pourtois e Desmet (1988), ela permite compreender mais profundamente as significações que possuem os participantes sobre os aspectos em estudo.

Inicialmente, foi feita a identificação das unidades significativas de conteúdo nos depoimentos, sujeito a sujeito, procurando dar destaque ao núcleo das ideias presentes nas manifestações discursivas. Na segunda etapa, os respondentes, por categoria, foram vistos em conjunto, e seus depoimentos foram agrupados por dimensões de análise. Esses procedimentos auxiliaram a identificação de suas posições a respeito das questões orientadoras da pesquisa e subsidiaram a interpretação das pesquisadoras. 


\section{Capítulo 2}





\section{A docência universitária e a formação para seu exercício}

O termo docência se origina da palavra latina docere, que significa ensinar, e sua ação se complementa, necessariamente, com discere, que significa aprender. Assim, docência, entendida como o exercício do magistério voltado para a aprendizagem, é a atividade que caracteriza o docente em geral. Na educação superior, docência e pesquisa são as principais atividades do professor universitário.

A docência universitária, apesar de ter pouca visibilidade, haja vista que os critérios de avaliação e progressão na carreira docente são essencialmente relacionados à pesquisa, é uma atividade altamente complexa, que não se restringe à sala de aula. Pressupõe um conjunto de atividades "[...] pré, inter e pós-activas que os professores têm de realizar para assegurar a aprendizagem dos alunos." (MARCELO GARCÍA, 1999, p. 243)

A docência, como atividade que articula os processos de ensino e de aprendizagem, teve sua complexidade reconhecida no século XVII por Comenius (1997) em especial na sua obra Didática Magna. Dizia o filósofo que 
Ensinar é a arte das artes é, portanto, tarefa árdua que requer o juízo atento não de um só homem, mas de muitos, porque ninguém pode ser tão atilado que não lhe escapem muitas coisas. (COMENIUS, 1997, p. 15)

As reflexões de Comenius (1997), ainda que valorizadas até nossos dias, nem sempre foram levadas a sério nas compreensões da prática educativa, tantas vezes vista conforme a racionalidade técnica dos modelos universais.

\section{A docência como atividade complexa}

Os estudos mais recentes sobre o professor e suas práticas assumem a complexidade da docência como um pressuposto. (CUNHA, 2006; SEVERINO, 2006) Essa complexidade se explica pelo fato de seu exercício, voltado para garantir a aprendizagem do estudante, e não para a mera transmissão de conteúdos, envolver condições singulares e exigir uma multiplicidade de saberes, competências e atitudes que precisam ser apropriados e compreendidos em suas relações. Assim, apesar de bastante difundida a crença de que o domínio dos conhecimentos específicos do campo científico ou profissional assegura a transposição para uma efetiva aprendizagem do estudante, a ausência de saberes pedagógicos limita a ação do docente e causa transtornos de naturezas variadas ao processo de ensinar e aprender.

Entre os saberes mobilizados cotidianamente na prática educativa, Tardif (2002a) destaca: saberes e ações de ordem técnica visando à combinação eficaz dos conteúdos, dos meios e dos objetivos educacionais; saberes e ações de natureza afetiva que aproximam o ensino de um processo de desenvolvimento pessoal; saberes e ações de caráter ético e político, sintonizados com uma visão de ser humano, de cidadão e de sociedade; saberes e ações voltados para a construção de valores considerados fundamentais; saberes e ações relativos à interação social, que revelam a natureza 
profundamente social do trabalho educativo e implicam o conhecimento mútuo e a co-construção da realidade por professores e estudantes.

Os saberes imprescindíveis à docência universitária, no dizer de Pimenta e Anastasiou (2002, p. 13), se articulam em torno de quatro eixos: 1) conteúdos das diversas áreas do saber e do ensino, ou seja, das ciências humanas e naturais, da cultura e das artes; 2) conteúdos didático-pedagógicos, diretamente relacionados ao campo da prática profissional; 3) conteúdos ligados a saberes pedagógicos mais amplos do campo teórico da prática educacional; 4) conteúdos ligados à explicitação do sentido da existência humana, com sensibilidade pessoal e social.

Aprofundando a reflexão sobre os saberes dos professores universitários que se relacionam com o eixo pedagógico, Cunha (2006) acrescenta:

- $\quad$ os saberes relacionados com o contexto no qual se desenvolve a prática pedagógica, que implicam a compreensão do papel da universidade na construção do Estado democrático, bem como das políticas que envolvem essas instituições;

- $\quad$ os saberes relacionados com a ambiência da aprendizagem, que envolvem o conhecimento das condições de aprendizagem de pessoas adultas e das múltiplas possibilidades que articulam conhecimento e prática social e os caminhos da integração no processo de aprendizagem do desenvolvimento cognitivo, afetivo-emocional, de habilidades e de atitudes;

- $\quad$ os saberes relacionados com o contexto sócio-histórico dos estudantes, que se traduzem em habilidades de compreensão da condição cultural e social dos estudantes, de estímulo às suas capacidades discursivas e de recomposição de suas memórias educativas, favorecendo uma produção do conhecimento articulada, de forma autobiográfica, e a afirmação de sua identidade social, cultural e pessoal; 
- os saberes relacionados ao planejamento das atividades de ensino, envolvendo as habilidades de delinear objetivos de aprendizagem, métodos e propostas de desenvolvimento de uma prática pedagógica efetiva, à capacidade de dimensionar o tempo disponível, em função da condição dos estudantes e das metas de aprendizagem e ao domínio do conhecimento específico de forma a situá-lo histórica e conjunturalmente e a estabelecer relações com outros conhecimentos;

- $\quad$ os saberes relacionados com a condução da aula nas suas múltiplas possibilidades, que pressupõem a condição do professor de ser o artífice, junto com os estudantes, de estratégias e procedimentos de ensino que favoreçam uma aprendizagem significativa, ancorada nas estruturas culturais, afetivas e cognitivas dos estudantes;

- $\quad$ os saberes relacionados com a avaliação da aprendizagem, que exigem um conhecimento técnico e uma sensibilidade pedagógica que permite, ao professor, a identificação das estratégias avaliativas que melhor informem sobre a aprendizagem dos estudantes, a partir da retomada dos objetivos previstos e da trajetória percorrida. Os saberes relacionados com a avaliação pressupõem, ainda, um posicionamento valorativo sobre os objetivos em questão e a capacidade de comunicar a avaliação aos estudantes.

A complexidade da docência universitária se explica, também, por seu caráter interativo, pois, como enfatiza Tardif (2002a), ensinar é desenvolver um programa de interações com os estudantes com vistas a determinados objetivos formativos que envolvem a aprendizagem de conhecimentos, mas, também, de valores, atitudes, formas de ser e de se relacionar. Pressupõe um processo complexo de negociação de expectativas, interesses, necessidades entre os atores envolvidos. Nesse sentido, conforme Altet (2001, p. 26), “[...] o professor profissional é, antes de tudo, 
um profissional da articulação do processo ensino-aprendizagem em determinada situação, um profissional da interação das significações partilhadas."

Esse caráter interativo configura a docência "[...] como uma prática social complexa carregada de conflitos de valor e que exige posturas éticas e políticas." (PIMENTA; ANASTASIOU, 2002, p. 14)

Reconhecer a interatividade como um traço característico da docência é considerar que o processo formativo se desenvolve num contexto grupal, em que pessoas com histórias de vidas distintas se implicam mutuamente. Isso coloca, para o professor, o desafio de compreender essa trama invisível que impacta os processos de ensino e de aprendizagem e de saber orientar o grupo de alunos para compreender essas implicações, aproveitando determinados elementos relacionais que emergem como objetos de análise e de aprendizagem sobre os conteúdos e sobre os valores e atitudes. $\mathrm{O}$ contexto grupal deixa de ser apenas o cenário no qual se desenrola a aula e é assumido como princípio educativo, voltado para a formação de cidadãos e profissionais reflexivos, críticos e solidários segundo a vivência concreta da sala de aula. Dessa forma, o professor, conforme Filloux (1970 apud SOUTO DE ASCH, 2007, p. 62, tradução nossa), assume também “[...] o papel de facilitador e explicitador de problemas técnicos ou afetivos no grupo $[. . .]^{\prime 2}$, de mediador da comunicação grupal.

Outro desafio que concorre para a complexidade da docência na educação superior diz respeito à especificidade do processo de aprendizagem de pessoas adultas na sua trajetória de formação profissional, mesmo se considerarmos que, na fase inicial da graduação, muitos estudantes estão ainda saindo da adolescência. Diversos estudos, cujo pioneiro foi o de Knowles (1984 apud MARCELO GARCÍA, 1999), evidenciam que o processo de aprendizagem de adultos pressupõe o seu engajamento consciente e voluntário. Isso equivale a dizer que eles precisam compreender

2 "[...] el rol de facilitador y elucidador de problemas técnicos ou afectivos en el grupo [...]" 
a finalidade de estudar os conteúdos apresentados, entender sua lógica e ter a possibilidade de negociar as formas propostas pelo professor para trabalhar esses conteúdos e para avaliar a aprendizagem realizada, pois, como explica o autor, a evolução do autoconceito do adulto é marcada pela passagem da dependência para a autonomia. A aprendizagem autônoma é, portanto, um dos aspectos fundamentais da educação de adultos e se caracterizaria pelo desenvolvimento da inteligência crítica, do pensamento independente e da análise reflexiva. (MERRIAM; CAFFARELLA, 1991 apud MARCELO GARCÍA, 1999)

A aprendizagem de adultos pressupõe ainda que suas variadas experiências sejam contempladas; que os conteúdos, objetos do ensino, tenham sentido para o aprendiz, que seja explicitado o seu papel social; que o ensino seja baseado na busca de solução de situações-problemas e na aplicabilidade dos conteúdos. Em síntese, a sua motivação para aprender é, principalmente, decorrente de fatores internos, ou seja, da sua compreensão acerca do sentido do quê e do como é ensinado.

A complexidade da docência universitária se configura, também, por ela ser um espaço de conexão de conhecimentos, subjetividades e culturas, que exige um conteúdo científico, tecnológico ou artístico altamente especializado, orientado para a formação de uma profissão. (LUCARELLI, 2004) Formação que, no dizer de Tardif (2002a), deve ser voltada para a reflexão, o discernimento e a compreensão de situações problemáticas do contexto da prática profissional e para a definição de objetivos pertinentes à situação e à identificação dos meios adequados para atingi-los. Isso implica, para o docente universitário, a tarefa de compreender criticamente a profissão em foco e o contexto mais amplo no qual ela se insere. Precisa, ainda, possibilitar, ao estudante, uma articulação consistente entre teoria e prática na formação de profissionais comprometidos com a transformação social, críticos, reflexivos e autônomos. Essa tarefa tem se tornado mais desafiante para os docentes, na medida em que: 
[...] o profissionalismo, longe de repousar principalmente na autonomia, na especialização e nos conhecimentos dos profissionais, remete a todo um jogo de negociações e tensões entre os profissionais, seus clientes e os organismos públicos ou privados que os empregam ou remuneram. (TARDIF, 2002b, p.93)

Pois, conforme o autor, os profissionais estão cada vez mais submetidos a duas lógicas, uma burocrática e tecnocrática e outra, do mercado, que contribuem para a redução da sua autonomia e, consequentemente, para a desprofissionalização, para a proletarização de alguns grupos profissionais e, "[...] em outros casos, subordinam a ética profissional à busca do lucro econômico ou ainda do poder." (TARDIF, 2002b, p.94)

A lógica do mercado, em outros termos, a mercantilização, que impacta fortemente o campo das profissões, também invade a educação superior e interfere nas práticas educativas dos docentes universitários. A transposição dessa lógica para a educação superior, conforme registra Naidoo (2008, p. 48), gera uma distorção na relação pedagógica entre professor e estudante, transformando-a numa relação entre prestador de serviços e clientes. Tal situação implica algumas consequências fundamentais para o processo formativo: 1) tendência, pelos estudantes, ao interiorizarem a identidade de clientes, de interpretar a aprendizagem como uma transação comercial e de se tornarem consumidores passivos; 2) possibilidade de haver a naturalização da visão de aprendizagem como um processo de seleção, consumo e reprodução de informações fragmentadas, desconexas, porém bem transmitidas pelo professor-prestador do serviço; 3) ao privilegiar o tratamento superficial dos conteúdos, gera prejuízo para o desenvolvimento de competências capazes de possibilitar uma aprendizagem autônoma, crítica e reflexiva; 4) estímulo à transformação do professor em refém dos estudantes-clientes, que, diante de suas ameaças e queixas, tende a abrir mão do método de questionamento às ideias 
existentes, do estímulo à reflexão crítica, optando “[...] Por uma 'formação segura' que permita transmitir aos estudantes conteúdo pré-definido e avaliável de forma convencional [...]"3 (NAIDOO, 2008, p. 52, tradução nossa)

Enfim, a docência do ensino superior é uma atividade complexa do ponto de vista político, social, intelectual, psicológico e pedagógico, cujos saberes e competências imprescindíveis ao seu exercício, sumariamente apresentados neste estudo, a configuram como um campo específico de intervenção profissional. Dessa forma, como acontece com as demais profissões, não podem ser adquiridos por imitação, e, sim, mediante uma formação específica e consistente.

\section{A formação do professor}

Formação é um fenômeno complexo sobre o qual existe pouco consenso no que concerne tanto às teorias quanto às dimensões mais relevantes para sua análise. A formação não deve ser confundida com outros conceitos, como educação, ensino, treino etc., pois envolve, necessariamente, uma dimensão pessoal de desenvolvimento humano global.

A formação de professor pode ser definida, conforme Marcelo García (1999, p. 26), como:

[...] a área de conhecimentos, investigação e de propostas teóricas e práticas que, no âmbito da Didática e da Organização Escolar, estuda os processos através dos quais os professores - em formação ou em exercício - se implicam individualmente ou em equipe, em experiências de aprendizagem através das quais adquirem ou melhoram os seus conhecimentos, competências e disposições, e que lhes permitem intervir profissionalmente no desenvolvimento do seu

3 “'[...] Por una 'formación segura', que permita transmitir a los estudiantes contenido predefinido y evaluable de forma convencional [...]" 
ensino, do currículo e da escola, com o objetivo de melhorar a qualidade da educação que os alunos recebem.

Essa formação, como enfatiza Ferry (apud MARCELO GARCÍA, 1999, p. 23), se diferencia de outras formações, em função, principalmente, de três aspectos: deve integrar a formação acadêmica (científica, literária, artística etc.) com a formação pedagógica; precisa ter como foco a formação de profissionais; se configura como formação de formadores e, como tal, exige o isomorfismo entre essa formação e a prática profissional que visa formar.

A formação de professores, inicial ou permanente, se diferencia de conceitos afins em função de três lógicas que lhe são inerentes, conforme Alin (1996 apud RODRIGUES, 2006, p. 26): lógica do investimento, lógica da formação-ação e lógica do projeto. A lógica do investimento pressupõe que o formando conhece e expressa suas necessidades, expectativas e desejos relativos à formação, os quais são levados em conta no processo formativo. Concebe o formando como um autor engajado, ativo e desejante, por isso "A formação implica uma acção profunda sobre a pessoa, agindo tanto sobre os saberes, à semelhança do ensino, como sobre as atitudes e os valores, tal como a educação" (RODRIGUES, 2006, p. 27), mas, por sua escolha e investimento, e, dessa forma, resulta no desenvolvimento pessoal e profissional. Assim, a formação acentua o caráter imprescindível do engajamento consciente, voluntário e responsável do sujeito no processo de sua formação; em outros termos, “[...] é o indivíduo, a pessoa, o responsável último pela activação e desenvolvimento de processos formativos." (MARCELO GARCÍA, 1999, p. 22) Pode-se concluir com o autor que

É através da interformação que os sujeitos - nesse caso os professores - podem encontrar contextos de aprendizagem que favoreçam a procura de metas de aperfeiçoamento pessoal e profissional. (MARCELO GARCÍA, 1999, p. 22) 
A lógica da formação-ação contempla o formando, autor, ativo e situado num contexto social e de trabalho, sobre o qual reflete, mediante o exercício do distanciamento, com vistas à resolução de problemas e a sua transformação. Nessa perspectiva

A organização da formação não se sujeita à lógica dos saberes disciplinares constituídos, de alguma forma intemporais na sua estruturação interna. Requer, pelo contrário, saberes marcadamente temporais, referenciados nos problemas a resolver, negociados com os formandos, individual ou coletivamente tomados, na sua especificidade de idade, contexto social, estádio de desenvolvimento, tempo, lugar. (RODRIGUES, 2006, p. 29)

A lógica do projeto coloca em evidência que a formação só é possível se o formando possuir projeto de aprender, de formar-se. Ela se configura, em última instância, como o espaço de negociação entre o projeto pessoal do formando, o projeto do formador e o projeto da instituição onde se desenvolve a formação.

A formação profissional do professor implica concebê-lo como ator/autor da sua trajetória de vida e emergente da teia econômica, social e cultural em que está inserido e como profissional que busca a formação, reconhece suas necessidades e as do contexto em que atua, se compromete reflexivamente na transformação das práticas e na afirmação da profissionalidade docente.

A formação desse profissional precisa garantir articulação entre teoria e prática, levando em conta a reflexão epistemológica da prática

[...] de modo a que aprender a ensinar seja realizado através de um processo em que o conhecimento prático e o conhecimento teórico possam integrar-se num currículo orientado para a ação. (MARCELO GARCIA, 1999, p. 29) 
Necessita da congruência entre a formação vivenciada pelo professor e o tipo de educação que posteriormente lhe será pedido que desenvolva; em outros termos, coerência entre o conhecimento didático do conteúdo, o conhecimento pedagógico transmitido e a forma de trabalhar esse conhecimento durante a formação. Contempla a individualização do processo de ensino-aprendizagem como elemento integrante de qualquer programa de formação de professores, o que implica a necessidade de conhecer as características pessoais, cognitivas, contextuais, reacionais de cada professor em formação e conhecer as necessidades e expectativas desses sujeitos como pessoas e como profissionais. Busca facilitar a interação do grupo em que se desenvolve o processo formativo, entendendo que as relações interpessoais amistosas e de confiança facilitam o crescimento individual e contribuem para a formação de profissionais capazes de trabalhar de forma colaborativa em torno de projetos curriculares na escola. Possibilita, aos professores em formação, o questionamento em relação às suas próprias crenças e práticas, a crítica propositiva em relação às orientações institucionais e, enfim, o seu crescimento intelectual, social, emocional e profissional.

\section{A formação do professor universitário}

Não existe uma tradição, nas sociedades ocidentais, de formação inicial do docente universitário; em contrapartida, em especial a partir da década de 1980, o título de doutor é exigido para ingresso no ensino superior. Na França, existem Centres d'Initiation à l'Enseignement Superieur (CIES), que formam futuros professores universitários. Nessa formação, os participantes, sob a supervisão de um professor-tutor pedagógico, realizam tarefas docentes, como aulas práticas e orientação de trabalhos de alunos, e frequentam cursos que abordam conteúdos, entre outros, sobre a função da universidade, os sistemas educativos, a 
organização do conhecimento e dos conteúdos didáticos, técnicas audiovisuais.

Salvo experiências isoladas, como a francesa, a formação desse professor tem se revelado, na prática, como um conjunto de atividades caracterizadas por sua brevidade e concreção, destinada a professores já contratados. Portanto, a participação em cursos com essa finalidade não se constitui em critério de seleção.

Diante do vazio da formação inicial dos docentes universitários, nas últimas décadas em diversos países, como Portugal e Espanha, cresce o interesse por essa formação e pelo desenvolvimento profissional ao longo da carreira. A formação dos professores iniciantes, considerados como aqueles cujo tempo de experiência varia, conforme os autores, de três a sete anos, não deve concebê-los como sujeitos passivos, acríticos e destituídos de conhecimentos e crenças a respeito desse nível de ensino. Eles construíram uma representação acerca da docência durante os anos em que foram estudantes universitários, com base na observação sobre a forma de seus professores ensinarem e envolverem ou não os estudantes no processo de aprendizagem, na participação em projetos de pesquisa, na experiência como representante estudantil nas atividades do departamento etc. Essas e outras vivências possibilitaram ao futuro professor universitário reproduzir estilos de ser professor, mas podem ter contribuído, também, graças ao processo de reflexão, para aprender o que não deve fazer como professor em razão dos efeitos negativos da sua experiência acadêmica.

O período de iniciação dos professores universitários na função do ensino é muito importante. Essa compreensão é traduzida pelo Ministério da Educação da Espanha (MEC, 1992 apud MARCELO GARCIA, 1999) em recomendações aos departamentos de que lhes seja atribuída uma menor carga docente, que sejam integrados em alguma linha de pesquisa, que lhes sejam assegurados tempo e meios para assistir a congressos e que sejam incorporados a grupos de discussão. Nesse processo de iniciação, 
pesquisas indicam a importância do papel do tutor ou mentor, "[...] professores experimentados que põem à disposição o seu conhecimento profissional." (MARCELO GARCÍA, 1999, p. 252) Todavia, diversos problemas, entre outros, falta de tempo e de disponibilidade, ausência de reconhecimento desse papel pelas instituições, tendem a inviabilizar o seu exercício.

\section{Desenvolvimento profissional de professores}

Desenvolvimento profissional se refere a uma determinada concepção de formação continuada dos professores em exercício, entendidos como profissionais da docência. Envolve uma perspectiva institucional e uma perspectiva pessoal do professor. $\mathrm{Na}$ perspectiva institucional, o desenvolvimento profissional pode ser entendido como um conjunto de ações sistemáticas que visam alterar a prática, as crenças e os conhecimentos profissionais dos professores, portanto vai além do aspecto informativo. Essas ações são assumidas não apenas individualmente, elas envolvem todos os profissionais que atuam de forma integrada na instituição, evidenciando, assim, a estreita ligação entre desenvolvimento profissional e desenvolvimento organizacional, o que pressupõe uma gestão democrática e participativa, capaz de alterar a própria organização, os papéis atuais e futuros dos professores, com base em reflexões críticas e propositivas do grupo, visando garantir, aos estudantes, aprendizagens significativas e crescimento pessoal.

$\mathrm{Na}$ perspectiva pessoal, o desenvolvimento profissional se projeta por uma disposição interna e uma postura de busca permanente de crescimento pessoal e profissional, disposição de refletir coletivamente sobre as práticas, atitudes e crenças individuais e coletivas, abertura para mudança. Em outros termos, desenvolvimento profissional é, conforme Rudduck (1987 apud MARCELO GARCÍA 1999, p. 137),

[...] a capacidade de um professor para manter a curiosidade acerca da classe; identificar interesses 
significativos no processo de ensino e aprendizagem; valorizar e procurar o diálogo com colegas especialistas como apoio na análise de dados.

Propõe, como indica Marcelo García (1999), desenvolver a capacidade de controle sobre as próprias condições de trabalho e possibilitar um avanço no estatuto profissional e na carreira docente.

O desenvolvimento profissional pressupõe a compreensão de que, antes ou depois da avaliação, é fundamental a promoção, pelas instituições universitárias, de ações diversas voltadas para o aperfeiçoamento da qualidade do ensino do professor universitário. Essas ações são mais eficazes quando tomam como ponto de partida e de chegada a prática profissional, objetivando o desenvolvimento de atitudes de reflexão e crítica sobre sua própria prática de ensino, quando priorizam as iniciativas dos próprios professores, em função da compreensão do caráter voluntário da formação, e quando investem na superação da perspectiva individualista da docência, apostando em ações colaborativas entre professores de um ou vários departamentos. Assim, é fundamental que os departamentos propiciem um clima de reflexão coletiva relacionada à didática e de apoio mútuo entre os professores, visando à melhoria da qualidade do processo ensino-aprendizagem.

O desenvolvimento profissional do professor universitário, conforme Villar Angulo (1993 apud MARCELO GARCIA 1999, p. 255), pode ser identificado segundo quatro modelos: modelo do processo de aperfeiçoamento individual; modelo de avaliação para aperfeiçoamento do ensino; modelo de indagação; e modelo organizacional. O primeiro modelo tem como pressuposto a ideia de que a profissão docente tem diferentes necessidades, que podem variar para cada professor. Portanto, deve ser oferecido um leque de ações, para que o professor escolha a que melhor atende suas necessidades de autodesenvolvimento profissional.

O modelo de avaliação para melhoria do ensino entende a avaliação do professor universitário não como uma ativida- 
de estanque e somativa, mas como o início de um processo de formação que busca o engajamento voluntário e a cooperação dos professores. Portanto, privilegia o diálogo e a negociação em oposição à norma e à imposição e, ainda, o aperfeiçoamento em oposição ao controle.

O modelo de indagação concebe o professor universitário como um profissional que investiga a sua própria prática e reflete sobre ela, por iniciativa própria ou por estímulo das instituições universitárias.

O modelo organizacional parte do pressuposto de que o desenvolvimento profissional deve ir além dos aspectos pessoais ou didáticos. Coloca em foco as mudanças estruturais e organizacionais da universidade, portanto é voltado para o aperfeiçoamento da comunicação, da democracia e do processo de tomada de decisões na universidade. A esse respeito, Santos Guerra (1993 apud MARCELO GARCIA 1999, p. 257), enfatiza que

[...] apelar ao aperfeiçoamento sem que se alterem as condições organizacionais da sua acção profissional (os mesmos espaços, a mesma proporção professor-aluno, os mesmos meios, os mesmos locais, o mesmo funcionamento etc.) é um convite grosseiro à exigência.

Com este capítulo, pretendemos contribuir para evidenciar a complexidade da docência universitária, que clama por sua afirmação como um campo profissional, ainda que a sua profissionalização e consequente construção de uma nova identidade impliquem o reconhecimento acadêmico-institucional, político, social e pessoal dos atuais e futuros professores universitários acerca da necessidade de sua formação específica. Essa formação, por sua vez, é também uma tarefa complexa e multifacetada, devendo centrar-se na reflexão sobre a epistemologia das práticas e assegurar, aos professores universitários em formação, um protagonismo que só poderá ser transposto para suas práticas educativas se vivenciado. 



\section{Capítulo 3}





\section{A pós-graduação e a formação de professores no contexto institucional brasileiro}

A formação de professorado competente para atender a expansão quantitativa e a elevação da qualidade do ensino superior, o estímulo ao desenvolvimento da pesquisa científica, mediante a formação consistente de pesquisadores e o treinamento de alto nível de técnicos e intelectuais para atender as necessidades do desenvolvimento nacional, configuram como motivações e finalidades centrais da pós-graduação no Brasil, sistematizadas no Parecer 977/65 da Câmara de Ensino Superior do Conselho Federal de Educação. (BRASIL, 1965) Sua elaboração teve o intuito de regulamentar os cursos de pós-graduação criados pela Lei de Diretrizes e Bases da Educação Nacional (LDB) N. 4.024/61 e passou a definir e normatizar os cursos de pós-graduação no Brasil até os dias atuais.

Conforme o Parecer 977/65, a pós-graduação stricto sensu, definida como um ciclo de cursos regulares, organizados sistematicamente no complexo universitário, visa desenvolver e aprofundar, pela via da pesquisa, a formação adquirida na graduação e culmina com a obtenção de um diploma desse grau acadêmico. Assim, a 
pós-graduação é assumida como "[...] cúpula dos estudos, sistema especial de cursos exigido pelas condições da pesquisa científica e pelas necessidades de treinamento avançado [...]" (BRASIL, 1965)

Fortemente inspirada no modelo norte-americano, a pósgraduação stricto sensu instituída no Brasil envolve dois níveis, mestrado e doutorado, que, embora hierarquizados, são relativamente independentes, ou seja, a realização do mestrado não é condição para ingresso no doutorado. Os processos de aprendizagem na pós-graduação stricto sensu caracterizam-se, de acordo com o parecer, pela flexibilidade e liberdade do pós-graduando de organizar seu percurso acadêmico sob a assistência de um orientador, de forma a cumprir um número determinado de créditos a partir da oferta de um elenco de disciplinas variadas na área de concentração, entendida como o campo específico do objeto de sua pesquisa. O programa de estudos comporta duas fases: a primeira implica a frequência às aulas, seminários, prova de leitura em língua estrangeira (pelo menos uma para o mestrado e duas para o doutorado) e é concluída com um exame geral que avalia a capacidade do pós-graduando de prosseguir os estudos. Ainda, as matérias devem ser, preferencialmente, "[...] ministradas sob a forma de cursos monográficos dos quais, seja em preleções, seja em seminários, o professor desenvolverá, em profundidade um assunto determinado." (BRASIL,1965) A segunda fase é dedicada, essencialmente, à pesquisa de um aspecto da área de concentração e culmina com a apresentação do documento da dissertação (mestrado) ou da tese (doutorado), que sistematiza os resultados da pesquisa empreendida.

Apesar de assumir como finalidade da pós-graduação a formação do professorado da educação superior, a estrutura geral dos cursos, expressa no Parecer 977/65, revela a ênfase dos programas na pesquisa. Ademais, conforme Lüdke (2005), a função de preparação do professor para atender a expansão do ensino superior, estabelecida por esse Parecer, não foi objeto de discussão acerca de 
como seria desenvolvida, de forma a ir além do aprofundamento de conteúdos de uma determinada área de conhecimento.

O Parecer 77/69 do Conselho Federal de Educação (BRASIL, 1969), cuja finalidade foi definir as normas de credenciamento dos cursos de pós-graduação em consonância com o Parecer 977/65, não faz qualquer referência à formação de professor da educação superior, o que revela um retrocesso em relação ao parecer que o precede. Em contrapartida, o artigo 13 estabelece que "O doutorado tem por fim proporcionar formação científica ou cultural ampla e aprofundada, desenvolvendo a capacidade de pesquisa e poder criador nos diferentes ramos de saber [...]" (BRASIL, 1969, p. 130) As finalidades do mestrado não são apresentadas.

Visando situar, do ponto de vista legal, o papel da pósgraduação stricto sensu na formação dos docentes universitários, consideramos fundamental um olhar panorâmico sobre os planos nacionais de pós-graduação. O Plano Nacional de Pós-Graduação (PNPG), de responsabilidade da CAPES, evidencia em cada período as prioridades do governo federal relativamente à pósgraduação. Esses planos assumem uma importância muito grande na trajetória da pós-graduação no Brasil, pois expressam o movimento de implementação planificada desse nível de ensino.

O I PNPG, referente ao período 1975-1980, relaciona, entre seus objetivos, a capacitação de docentes universitários e de pesquisadores, a integração da pós-graduação no sistema universitário e o desenvolvimento da pesquisa na universidade. A preocupação com a formação dos professores universitários, já em exercício e dos futuros, está presente em todo o texto. O plano expressa que, assim como o ensino superior visa à formação de recursos humanos para os demais níveis de ensino e para a sociedade, “[...] os cursos de pós-graduação no sentido estrito - mestrado e doutorado - devem ser regularmente dirigidos para a formação de recursos humanos para o próprio ensino superior [...]" (BRASIL, 1974, p. 120)

Essa perspectiva tem como pressuposto a ideia de que " $[. .$. o ensino e a pesquisa devem estar integrados em todos os níveis, 
e os vários níveis devem estar articulados entre si [...]" (BRASIL, 1974 p. 120) Essa articulação é reforçada por esta proposição:

[...] os docentes qualificados para o ensino de pós-graduação participem do ensino de graduação; e que os alunos de pós-graduação, sempre que possível e oportuno, apóiem estas tarefas na qualidade de monitores e auxiliares de ensino, oficialmente designados e com direito a bolsa de complementação. (BRASIL, 1974, p. 131)

A ênfase atribuída pelo I PNPG à formação do professor universitário é registrada por Marques em entrevista a Bianchetti (2005), ao afirmar que, até a década de 1970, era forte, em cursos de mestrado, a preocupação da CAPES com a formação do professor da educação superior, apesar de, na prática, o desafio da formação do professor do ensino médio e fundamental ter se imposto nos programas de educação stricto sensu. A partir desse período, com a implantação dos cursos de doutorado, a ênfase, conforme Marques, passa a ser a formação do pesquisador.

Cabe, entretanto, ressaltar que, a despeito de enfatizar a importância da docência universitária e a necessidade de sua formação em nível de pós-graduação, o I PNPG não fornece elementos que evidenciem o caráter pedagógico dessa formação, subsumindo a formação para a docência à formação para a pesquisa, o que pode ser depreendido quando, no que tange à natureza operacional do funcionamento do curso de pós-graduação stricto sensu, destaca como suas atividades: as científicas e as profissionais. As atividades científicas envolvem a organização de linhas regulares de projetos de pesquisa, a produção de trabalhos profissionais de comunicação e a discussão e o intercâmbio de informações e temas culturais, científicos e técnicos, que são realizados por grupos de pesquisa. As atividades profissionais compreendem

[...] o preparo e a execução de projetos técnicos e organizacionais específicos para assessorar no 
desenvolvimento do sistema produtivo e na formulação de planos e políticas governamentais. (BRASIL, 1974, p. 133)

O II PNPG, que abarca o período 1982-1985, apresenta como objetivo central a

[...] formação de recursos humanos qualificados para atividades docentes, de pesquisa em todas as suas modalidades, e técnicas, para atendimento às demandas dos setores público e privado [...] (BRASIL, 1982)

Entretanto, a formação docente parece ter uma importância muito menor do que no plano anterior, como pode ser observado neste trecho:

A pesquisa original não é o único mecanismo de capacitação e aperfeiçoamento no magistério. Uma atualização permanente por meio do acompanhamento das publicações especializadas mais recentes e da participação em congressos, seminários, encontros e intercâmbios, junto com o exercício corrente de outras atividades de produção intelectual, como a elaboração de textos didáticos, a publicação de artigos, resenhas ou comentários, são igualmente necessários para a constituição de um corpo docente atualizado e competente. (BRASIL, 1982, p. 179-180)

Ressituar o papel da pesquisa na formação do docente universitário, entretanto, não implicou colocar em relevo outros saberes e competências que seriam assumidos pelos cursos de pós-graduação, o que seria desejável, considerando que a formação desse profissional aparece como objetivo do II PNPG. Ao que tudo indica, essa visão não tem como pressuposto uma concepção mais ampla da docência universitária, mas o seu oposto, na medida em que subestima a pesquisa como um princípio educativo no 
exercício da docência na graduação. A esse respeito, é ilustrativo o trecho

Embora para a esfera acadêmica a estreita vinculação entre ensino e pesquisa continue uma diretriz fundamental, ela não se aplica universalmente a todos os âmbitos e modalidades científico-culturais. (BRASIL, 1982, p.179)

A pesquisa é considerada uma atividade de excelência para um grupo seleto de docentes situado no interior da pós-graduação stricto sensu, a qual teria, principalmente, o objetivo de formar pesquisadores. (BRASIL, 1982, p. 188) Isso porque, na visão dos formuladores do II PNPG, a implementação das diretrizes do III Plano Nacional de Desenvolvimento (III PND) - e com as indicações do III Plano Básico de Desenvolvimento Científico e Tecnológico (III PBDCT) - pressupunha a

[...] participação ativa de um número crescente de profissionais, pesquisadores e docentes altamente qualificados, em todos os setores da vida nacional. Cabe à pós-graduação, portanto, o papel central na sua formação e no seu aperfeiçoamento, em número suficiente e com qualificações adequadas às necessidades do País. (BRASIL, 1982, p.183)

O III PNPG, que compreende o período de 1986 a 1989, elaborado na fase inicial da Nova República, coloca o foco na institucionalização e ampliação da pesquisa, entendida como elemento indissociável da pós-graduação, na consolidação do papel da pós-graduação stricto sensu, como instrumento de desenvolvimento científico, tecnológico, social, econômico e cultural, e na sua integração ao sistema nacional de ciência e tecnologia. Nessa medida, estabelece a universidade como ambiente privilegiado para a produção de conhecimento, na perspectiva do desenvolvimento nacional autônomo. Assim, no que tange a seu papel formativo, o foco da pós-graduação é a formação do "cientista", do pesqui- 
sador, considerando que o país, "[...] não possui um quantitativo de cientistas que permita, a curto prazo, atingir plena capacitação científica e tecnológica." (BRASIL, 1986, p. 193) A formação para a docência universitária não é referida nesse plano. Em síntese, seus objetivos são: 1) consolidação e melhoria do desempenho dos cursos de pós-graduação; 2) institucionalização da pesquisa nas universidades, para assegurar o funcionamento da pós-graduação; 3) integração da pós-graduação no sistema de Ciência e Tecnologia e com o setor produtivo. (BRASIL, 1986, p. 195)

O IV PNPG não chegou a se expressar num documento final. No longo intervalo entre o III e o V PNPGs, do ponto de vista legal, ganha evidência, para nosso objeto de estudo, a promulgação da Lei de Diretrizes e Bases da Educação Nacional, Lei № 9.394/96. Esta LDB não faz referência à formação do professor do magistério superior, mas, em contrapartida, estabelece, no artigo 66, que sua “[...] preparação far-se-á em nível de pós-graduação, prioritariamente em programas de mestrado e doutorado." (BRASIL, 1996) Essa preparação, entretanto, não é obrigatória, conforme indica o termo prioritariamente e a definição do limite mínimo de um terço do corpo docente com titulação acadêmica de mestrado ou doutorado, que consta no artigo 52, inciso II dessa lei.

O V PNPG, referente ao período de 2005 a 2010, volta a colocar, entre seus objetivos, a formação de docentes, dessa vez ampliada para todos os níveis de ensino, ao lado dos objetivos de fortalecimento das bases científica, tecnológica, de inovação e de formação de quadros para mercados não acadêmicos.

No que concerne à formação do corpo docente da educação básica, considerando a sua qualificação deficitária, principalmente na etapa do ensino fundamental, a pós-graduação stricto sensu deveria contribuir, mediante o desenvolvimento de pesquisas, para

[...] encontrar os melhores métodos e técnicas de educação a distância que possibilitem a formação qualificada do universo docente em atividade, 
aproveitando-se das iniciativas exitosas existentes no país. (BRASIL, 2004, p. 60)

No tocante à formação de quadros para mercados não acadêmicos, o V PNPG enfatiza as empresas estatais brasileiras, que, além de necessitar, para sua modernização, de recursos humanos altamente capacitados, podem realimentar, financeiramente, a pós-graduação nacional. Destaca, ainda, a importância do papel da pós-graduação na formação de pessoal qualificado para diversas outras áreas governamentais, como educação, saúde, cultura, segurança pública e para organizações não governamentais. Afirma que

[...] A interação da pós-graduação com o setor empresarial, para a especialização de funcionários de empresas através de cursos de Mestrado, deverá ser valorizada, uma vez que indica uma maior inserção do Programa na sociedade. (BRASIL, 2004, p. 63)

A formação do docente da educação superior, entretanto, não é objeto de qualquer reflexão específica. Recomenda apenas que seja

[...] considerada na política de pessoal das instituições de ensino superior a absorção de no mínimo $5 \%$ ao ano de novos mestres e doutores e a duplicação em dez anos do número de pesquisadores qualificados, conforme disciplina a Lei do Plano Nacional de Educação [...] (BRASIL, 2004, p. 61)

Ao que tudo indica, a concepção de formação de docente universitário subentendida nesse plano se restringe à formação para a pesquisa. Corroboram com esse entendimento as formulações:

A redefinição do papel do mestrado reforça a iniciação científica na formação de pesquisador, sugerindo-se a atribuição de créditos às ativi- 
dades que resultem em produção científica ou tecnológica. Para a consolidação de determinadas áreas do conhecimento deve-se atribuir créditos às atividades de pesquisa, além daqueles das disciplinas formais. A forma e o elenco das disciplinas deverão ser dimensionados de acordo com as necessidades do estudante e da área de formação. (BRASIL, 2004, p.59)

A pós-graduação deve ser aferida pela qualidade da produção científica e tecnológica dos grupos de pesquisa que a compõem. O número de doutores titulados que saíram da Iniciação Científica diretamente para o Doutorado deverá ser levado em conta na classificação dos centros de pós-graduação. (BRASIL, 2004, p. 63)

A análise dessas peças legais permite evidenciar uma concepção restrita da docência universitária, centrada no domínio dos conteúdos dos campos científicos e na competência de fazer pesquisa. Os desafios crescentes do processo político-pedagógico que caracterizam a sala de aula da universidade e a formação de profissionais, sob responsabilidade dos docentes da educação superior, não são objetos dos planos da instituição responsável pela coordenação e aperfeiçoamento do pessoal da educação superior.

A docência e a pesquisa são atividades distintas que podem se articular e contribuir efetivamente para a formação de profissionais autônomos, críticos, reflexivos e comprometidos com a transformação social. Como registra Paoli (1988), a experiência na universidade indica que essas atividades têm naturezas distintas, portanto a interação entre elas não se concretiza a priori, espontaneamente, depende de um conjunto de fatores que envolve desde as políticas educacionais e científicas, recursos, equipamentos, espaço, tempo até a postura dos profissionais que desenvolvem esses trabalhos. Essa interação pressupõe uma mediação que se sustenta em saberes do campo didático-pedagógico, que resultam 
de aprendizagens declarativas, formais e vivenciais. Em que espaço seriam construídas essas e outras aprendizagens necessárias ao exercício da docência universitária? Os documentos analisados não conseguem responder a essa indagação.

\section{A pós-graduação em educação e a formação do docente universitário}

A pós-graduação em educação, subárea da grande Área de Ciências Humanas, ao longo da sua trajetória, reflete, em relação à formação do docente universitário, as políticas expressas nos documentos anteriormente analisados.

A implementação da pós-graduação stricto sensu em educação, que se inicia em 1966 com a criação do mestrado em educação da Pontifícia Universidade Católica do Rio de Janeiro, assim como das demais áreas,

[...] vai acontecer no contexto do projeto de modernização conservadora, capitaneado, nas suas origens, pelo regime militar, cujas metas, definidas nos planos de desenvolvimento nacional implantados no pós-1964, apontam para a formação de recursos humanos qualificados para todos os níveis de ensino, a preparação de pesquisadores de alto nível e a capacitação avançada de profissionais. (RAMALHO; MADEIRA, 2005, p. 71)

Na primeira fase, sob a égide do recém-criado Parecer 977/65 e depois do I PNPG, a pós-graduação em educação, em particular os mestrados, visava, prioritariamente, à formação do professor do ensino superior, mediante a titulação de mestres e doutores para ingresso e promoção na carreira universitária. Como registra Fávero (1993, p. 31):

Em muitos programas de pós-graduação em educação, o objetivo de preparar técnicos de alto 
nível foi intimamente associado à formação de docentes, sobretudo nos cursos que tinham como áreas de concentração o ensino, a metodologia didática, a tecnologia educacional etc.

A ênfase na formação de pesquisadores, assumida como objetivo principal do sistema de pós-graduação, na educação começa a se consolidar, sobretudo na década de 1990, pois, até aquele momento, a estrutura dos cursos não privilegiava a pesquisa, concepção e prática, como motor da pós-graduação.

O incentivo e apoio por parte da CAPES para criação das associações de pós-graduação, como a Associação Nacional de Pós-Graduação e Pesquisa em Educação (ANPED), se inserem no processo de fortalecimento dos programas, cujo centro é a pesquisa, como afirma Darcy Gloss (1986 apud FÁVERO, 1993, p. 36), diretor-geral da CAPES no início da década de 1970.

Esse processo evidenciou avanços, dentre os quais, Ramalho e Madeira (2005) destacam: a consciência crescente da importância da integração entre pesquisa e ensino; o entendimento do ensino como construção coletiva pela via da relação entre teoria e prática; e a estruturação de linhas de pesquisa. Todavia, a configuração da pesquisa com papel definidor da pós-graduação em educação se verificou

[...] não sem o duplo risco do descuido da formação pedagógica e didática de novas gerações de mestres e doutores, e da vulgarização ou da superficialidade da pesquisa. (RAMALHO; MADEIRA, 2005, p. 79)

Assim, para se afirmar no sistema mais geral, a pós-graduação em educação parece perder de vista a sua especificidade.

Com efeito, a pós-graduação em educação, estruturada com base nas diretrizes dos Pareceres 977/65 e 77/69, que preconizam a organização dos cursos em áreas de concentração, com elenco 
de disciplinas obrigatórias e eletivas, conforme Frigotto (apud FÁVERO, 1993, p. 34), padece de certa padronização atribuída a:

[...] de um lado, pela prática do credenciamento dos cursos pelo CFE, nos moldes cartoriais que lhe são próprios, exigindo o cumprimento exato das normas estabelecidas; e, de outro, pelo clima de pouquíssimo debate no período, fruto do regime autoritário e do espírito de subserviência que penetrou fundo em todas as instituições brasileiras.

Os testemunhos que foram mencionados indicam que, a despeito dos avanços da pós-graduação em educação, a busca de sua afirmação no conjunto do sistema de pós-graduação tem determinado a diluição da sua natureza específica, didática e pedagógica, e da missão, expressa no parecer que institucionaliza esse sistema de ensino no Brasil, de formar o docente universitário, que resta subsumida pela formação do pesquisador.

\section{Os programas de pós-graduação em educação objetos de estudo}

Os dois programas de pós-graduação em educação, aqui denominados PPGE1 e PPGE2, se desenvolvem no interior de universidades públicas. Possuem tempos de existência bastante diferentes: o PPGE1 está em funcionamento há décadas; e o PPGE2, há menos de uma década. Assumem o curso de mestrado e de doutorado, embora o PPGE2 ainda não tenha formado a sua primeira turma de doutores. Receberam o conceito quatro nas últimas avaliações da CAPES.

O PPGE1 desde sua criação esteve voltado para o entendimento dos processos que se desenrolam na educação básica, variando, ao longo da sua trajetória, de enfoques e perspectivas. Na sua história, a preocupação com a formação do docente do ensino superior se dá não pela pós-graduação stricto sensu, mas pela 
especialização com o curso de Metodologia do Ensino Superior, em diversas edições.

Conforme o regimento do PPGE1 ${ }^{4}$, seus objetivos são: a) Formação de pesquisadores para as instituições de modo geral; b) Desenvolvimento da atividade de pesquisa educacional; c) Interação entre pesquisadores reconhecidos, pesquisadores em formação, profissionais que trabalham no campo da educação e estudantes; d) Produção de conhecimentos a partir de análises de situações concretas no campo da educação e suas relações com a sociedade; e) Produção de referenciais teórico-metodológicos para a compreensão do processo educativo e das relações educação - sociedade. É oportuno destacar que a formação do docente universitário não integra esse rol de objetivos.

O currículo desse programa envolve disciplinas obrigatórias e optativas, comuns aos dois cursos, atividades e trabalho de conclusão, que variam para o mestrado e o doutorado. As disciplinas obrigatórias são: 1) Abordagens e técnicas de pesquisa em educação e 2) Educação, sociedade e práxis pedagógica. As disciplinas optativas são oferecidas no interior das linhas de pesquisa Currículo e (In)Formação: Filosofia, Linguagem e Tecnologias, Políticas e Gestão da Educação, Educação e Diversidade e Educação, Cultura Corporal e Lazer.

O conjunto das disciplinas optativas revela a preocupação das linhas, todas voltadas para a produção de conhecimentos acerca da função social da escola, da compreensão dos seus processos filosóficos, epistemológicos, sociopolíticos, pedagógicos e da formação do educador da educação básica.

Em relação às atividades, no mestrado, o regimento do PPGE1 estabelece como obrigatórias: Projeto de Dissertação, Pesquisa Orientada visando à elaboração da dissertação e Tirocínio Docente. No doutorado, as atividades obrigatórias são: Projeto de Tese,

${ }^{4}$ Endereço eletrônico: http://www2.faced.ufba.br/pos_grad/regimento 
Exame de Qualificação e Pesquisa Orientada visando à elaboração da tese.

O PPGE2, no seu regimento, apresenta como objetivos: 1) Contribuir para a elevação da competência acadêmica, científica e profissional de educadores que atuam em diversos espaços, entre eles a universidade e a escola, e para o desenvolvimento sustentável das comunidades em seu entorno social; 2) Fomentar, no interior dos grupos de pesquisa, a articulação entre os processos formativos desenvolvidos na graduação, nos cursos lato sensu e nas atividades de extensão, e a pós-graduação stricto sensu; 3) Capacitar profissionais para intervir na realidade educacional nas diversas regiões do Estado, visando à preservação dos recursos naturais, do patrimônio cultural e do desenvolvimento humano na perspectiva do desenvolvimento sustentável; 4) Proporcionar uma formação acadêmica que contemple a dimensão da formação do pesquisador em educação e a dimensão do exercício da docência universitária; 5) Ampliar e consolidar intercâmbios e parcerias institucionais visando à cooperação acadêmica e técnica para o avanço do conhecimento.

Vê-se que a formação do docente universitário integra o conjunto dos objetivos declarados do PPGE2.

O currículo do PPGE2 contempla disciplinas obrigatórias para todos os pós-graduandos e disciplinas obrigatórias específicas de cada linha. As disciplinas obrigatórias e específicas variam conforme o curso de mestrado e doutorado.

As disciplinas obrigatórias para os mestrandos são: Bases Filosóficas da Contemporaneidade; Educação e Contemporaneidade e Pesquisa em Educação. As disciplinas específicas das linhas, obrigatórias ou optativas, revelam a preocupação com a produção de conhecimentos acerca da função social da educação formal e não formal, da compreensão dos seus processos históricos, epistemológicos, sociopolíticos, pedagógicos, da gestão e sua contribuição para o desenvolvimento local sustentável e da formação do educador da educação básica. 
No doutorado, as disciplinas obrigatórias são: Estudos Avançados de Educação e Contemporaneidade; Seminário de Formação Teórico-Metodológica I e Seminário de Formação Teórico-Metodológica II.

As atividades obrigatórias do mestrado, conforme o regimento do PPGE2, são: Estudos Orientados (constituídos das atividades de orientação desenvolvidas na relação orientador e mestrando com vistas à produção da dissertação); Fórum de Pesquisa em Educação; Tirocínio Docente; Exame de Qualificação e Dissertação (que envolve o texto escrito e a defesa pública).

O Tirocínio Docente tem a finalidade de "[...] preparar o mestrando para o desempenho da função docente no ensino superior." ${ }^{5}$ O regimento não especifica se esta atividade é obrigatória apenas para os bolsistas da CAPES, o que sugere a obrigatoriedade para todos que não comprovarem experiência no ensino superior. Todavia, o regimento, também, prevê a possibilidade de sua realização em funções docentes vinculadas a processos formativos formais e não formais, em qualquer nível de ensino e em instituições de naturezas jurídicas diversas.

No doutorado, as atividades obrigatórias envolvem: Pesquisa Orientada; Fórum Pesquisa em Educação; Tese correspondente ao relatório do trabalho de pesquisa original e inédito.

A análise dos documentos desses programas indica a existência, no caso do PPGE2, de intenções políticas expressas, nos seus objetivos, relacionadas à formação do docente universitário. Todavia, quando se verifica o conjunto das disciplinas obrigatórias e optativas e as atividades, salvo o Tirocínio Docente, fica evidente a ausência de diferenças entre os dois programas, no que tange à formação do docente universitário. A ênfase na pesquisa parece ser assumida numa perspectiva exclusivista e desarticulada da formação para o exercício da docência universitária. Ademais, o foco das pesquisas, ao que tudo indica, é a produção de conhecimentos acerca da função social da escola, da compreensão

${ }^{5}$ Trecho do Regimento de um dos programas em estudo. 
dos seus processos filosóficos, epistemológicos, sociopolíticos, pedagógicos e da formação do educador, especificamente, da educação básica. 


\section{Capítulo 4}





\section{Programas de pós-graduação em educação e a formação de professor universitário na perspectiva dos egressos}

Na sistematização das contribuições dos egressos dos programas foram levados em conta os seguintes aspectos: as motivações para escolha do programa; as principais aprendizagens e repercussão na atuação docente dos egressos; a formação do professor universitário; a regulamentação da docência universitária.

\section{As motivações dos egressos em relação aos programas de pós-graduação em educação}

A motivação dos participantes para fazer a pós-graduação stricto sensu tem, principalmente, natureza pragmática. Com efeito, para a maioria, que ao iniciar o mestrado não atuava no ensino superior, a motivação era adquirir o passaporte para o ingresso no magistério desse nível de ensino, considerando as exigências da Lei 9.394/96. Para a minoria, que atuava como docente universitário, a motivação era progredir na carreira. 
A opção por programas de pós-graduação stricto sensu em educação, e não em programas de seus respectivos campos da graduação, parece ser explicada pelo fato de que, dos sete egressos, todos atuavam na área de educação, cinco, na educação básica, e dois, em uma universidade pública.

A expectativa de adquirir saberes e competências específicos da docência universitária, na fala dos dois participantes que já a exerciam, foi evocada em segundo lugar. Cabe destacar que um deles justificou essa expectativa por considerar a docência universitária como uma atividade complexa, cujo exercício pressupõe o entendimento dos processos formativos, e a importância do professor na constituição dos sujeitos envolvidos no processo. Todavia, mesmo esses participantes tomaram como objetos de pesquisa aspectos relacionados à escola básica.

A opção por objetos de pesquisa não vinculados à docência universitária poderia ser explicada pelo fato de que os programas de educação, em estudo, não contemplam a pedagogia universitária como linha de pesquisa. Entretanto, o não-reconhecimento da pós-graduação stricto sensu como espaço para a construção dos saberes da docência universitária pode também estar relacionado à representação, dominante, de que, para ser professor, é suficiente ter o domínio dos conteúdos específicos da área de conhecimento, o dom da oratória e a competência como pesquisador. É natural, então, que a pós-graduação tenha como foco a formação do pesquisador e que não exista um espaço destinado à formação para a docência universitária.

Essa hipótese parece ganhar força quando, espontaneamente e de forma unânime, os participantes afirmaram que, no que tange à sua ação docente e à condição de professor, a experiência no Programa de Pós-Graduação em Educação (PPGE) representou, além da possibilidade de ascensão profissional e financeira, amadurecimento intelectual, maior embasamento para o exercício da prática educativa, ressignificação das suas práticas na educação básica. 


\section{Principais aprendizagens nos programas e repercussão na atuação docente na educação superior dos egressos}

Os egressos, por unanimidade, expressaram que as principais aprendizagens adquiridas nos programas de pós-graduação em educação foram realizar pesquisa e publicar seus resultados. Assim, quando interrogados sobre os aspectos em que se sentem mais aptos, a partir dessa formação, apontam:

- [...] realizar pesquisa, elaborar relatórios, lecionar. O mestrado me permite hoje a segurança necessária para desenvolver pesquisa em diversos âmbitos; estou apta a continuar meu trabalho como professora-pesquisadora e pessoa humana; diria que (o principal objetivo do programa) formar o professor pesquisador... ou o educador pesquisador, mas a pesquisa fortemente imbuída de uma prática autônoma. Acredito que o mestrado foi mais importante na formação de pesquisadora.

É pertinente destacar que os participantes não verbalizaram a contribuição dessa formação para a implementação da pesquisa no exercício da docência. Essa lacuna pode indicar a naturalização da pós-graduação como o espaço próprio da realização de pesquisa e, portanto, da implementação, na universidade, do princípio da indissociabilidade entre ensino, pesquisa e extensão. Essa situação de separação organizacional entre produção e consumo de conhecimento na vida da universidade, que tende a se configurar na prática a partir da criação da pós-graduação stricto sensu no Brasil, na década de 1960, como indica Paoli (1988), concorre para a transformação da graduação em lugar de consumo de conhecimento, e a pós-graduação, em espaço de produção de conhecimento. Todavia, acrescenta o autor, essa separação entre 
produção e consumo, entre pesquisa e ensino, se verifica, também, no interior da própria pós-graduação na medida em que

[...] a estrutura dos programas, sendo articulada na obrigatoriedade do cumprimento de créditos relativos às disciplinas, tem criado, muitas vezes, um percurso onde as atividades relacionadas à pesquisa para a produção da tese ou dissertação ficam coibidas ou penalizadas durante o período dedicado à 'integralização' de créditos de cursos. (PAOLI, 1988, p. 33)

Além de aprender a pesquisar, os participantes revelaram ter conquistado maior aprofundamento teórico sobre seus objetos de pesquisa, o que repercutiu na melhoria da capacidade de dar aula:

- O grande ganho foi na área objeto de estudo;

O Mestrado contribuiu no aprofundamento como professor do ensino superior, principalmente, nas questões que estudei; $\mathrm{O}$ mestrado possibilitou um aprofundamento na área de Psicologia sócio-histórica [...] Estou mais segura para trabalhar os conteúdos; Aprendemos a buscar o conhecimento. Quando voltei do mestrado sentia necessidade de ler mais para preparar minhas aulas.

Esse aspecto bastante valorizado pelos participantes suscita uma reflexão. Se o domínio de conteúdos específicos é parte indispensável do arsenal de que precisa o docente universitário para assegurar que seu ensino seja capaz de engendrar aprendizagens nos estudantes, ele não é suficiente. Para que o professor da educação superior contribua para a construção do saber pelo estudante, é preciso que ele próprio domine, também, uma gama de saberes, entre os quais, os saberes pedagógicos. Essa perspecti- 
va vai emergindo lentamente quando os egressos são provocados a falar sobre outros saberes necessários à docência universitária.

Alguns egressos testemunharam a realização de aprendizagens que incidiram diretamente na sua forma de desenvolver a docência:

- O mestrado abre seu campo de atuação, você passa a ter um olhar investigativo sobre as coisas, isto na educação é importante, para fazer o aluno questionar, criar, ver o que está por trás das coisas; Passei a dar mais voz ao estudante [...] Apesar das carências, o mestrado proporcionou maior embasamento para minha prática pedagógica, pois provocou muitos desafios, entramos no lugar do aluno, e passamos a questionar nossa prática como professor; Mudei a forma de planejar a sala de aula... antes o planejamento era muito extenso [...] depois do mestrado, ficou mais racional, mais focado na ementa, na realidade da região e do curso, possibilitando maior aprofundamento dos conteúdos trabalhados; O mestrado ajudou a desenvolver a capacidade de argumentar.

Esses depoimentos evidenciam que os programas de pósgraduação em educação contribuíram, de alguma forma, para a melhoria da docência dos participantes e que a investigação, o questionamento, a articulação teoria e prática são elementos importantes do currículo voltado intencionalmente para a formação do docente da educação superior.

Outras aprendizagens, decorrentes da formação vivida na pós-graduação em educação, foram referidas por apenas um participante, tais como: uma melhor compreensão da educação 
superior, em especial no que tange à trilogia ensino, pesquisa e extensão, repercutindo em maior compromisso com a universidade; a ampliação da visão acerca do valor da educação como instrumento de transformação social; e a descoberta de que a graduação, apesar da ação de alguns professores mais críticos, tem sido muito tradicional e voltada para o adestramento. Embora minoritárias, essas proposições são muito significativas para o entendimento do papel da pós-graduação stricto sensu na formação do professor universitário. Indubitavelmente, a docência universitária pressupõe o conhecimento e a reflexão crítica sobre a universidade, seu papel histórico e social, os princípios que regem ou deveriam reger seu funcionamento, sua relação com o contexto social e com o mercado. Ademais, possibilitar uma análise crítica, ainda que superficial, do ensino na graduação e da contribuição da educação no processo de transformação da sociedade é parte do processo de formação desse professor.

\section{A formação do professor universitário na perspectiva dos egressos}

Aprender a fazer pesquisa, principal conquista da experiência vivenciada, tem efetivamente um sentido especial na formação do professor universitário. Contudo, como registram diversos autores (CUNHA, 2006; MARCELO GARCIA, 1999), essa formação não contempla toda a complexidade da docência do ensino superior. Imbuídos dessa compreensão, estimulamos os participantes a expressar suas concepções acerca da formação do docente da educação superior. É relevante registrar o estranhamento de alguns frente a essa temática e a informação de que nunca haviam pensado sobre tal questão. Essa manifestação, aliada ao fato de que nenhum participante fez referência à formação inicial específica para a docência universitária, revela a falta de uma cultura, no interior da universidade, de formação desse professor e a tradição 
de escassa reflexão sobre a sua profissionalização, na medida em que esta remete a uma formação específica de alto nível.

A graduação é, naturalmente, assumida como a condição mínima necessária para ingresso no ensino superior, sendo sugerido por um participante que ela passe a se preocupar, também, com a formação para a docência universitária, com a justificativa de que "- A tarefa de professor é semelhante independente do nível, o que vai mudar são as atribuições. É necessário aprender a ser professor tanto para o $2^{\underline{0}}$ grau quanto para o $3^{\circ}{ }^{\circ}$. Nessa perspectiva, os estudos de pós-graduação se configurariam como uma formação continuada: "-Para ser professor do ensino superior tem que ter graduação, mas não pode parar, tem que ter formação continuada." O mestrado, pensado como espaço de formação do professor da educação superior, deveria incluir a pedagogia universitária na visão de outro participante e " - [...]deveria contemplar o conceitual, mas seguir o modelo das bonecas russas. Uma formação que estimulasse as pessoas a pensar e atuar na sala de aula. Ter a sala de aula como objeto de reflexão e estudo." Entretanto, não emergiram sugestões de criação, nos programas, de linhas de pesquisa relacionadas à docência universitária.

A formação continuada aparece, também, nos moldes de iniciativas não formais. Assim, alguns participantes propuseram que essa formação, posterior à graduação, deveria ser uma espécie de formação em exercício:

- [...] no convívio com outros profissionais dispostos a compreender e a atuar na formação de pessoas [...] Um lugar criado pelos sujeitos do próprio lugar [...] Esta formação tem que ser na faculdade de educação, a não ser que a física pensasse a formação do professor de física; em núcleos de pesquisa e centro de formação do docente, pois o professor está preparado na área de sua formação 
(engenharia etc.). Esse centro é para dar uma formação contínua, algumas universidades têm, mas acaba.

A formação, a partir de iniciativas não formais, concebida pelos respondentes, se aproxima da perspectiva do desenvolvimento profissional, entendido como conjunto de ações sistemáticas, pessoais ou institucionais, que visam ao aperfeiçoamento dos conhecimentos, das práticas docentes e atitudes dos professores como profissionais, a partir de seu efetivo engajamento. Implica uma disposição interna e uma postura do professor de busca permanente de crescimento pessoal e profissional e de reflexão individual e coletiva sobre suas próprias práticas, como docente.

Interessante notar que a reflexão e a crítica sistemáticas, entre os pares, e o desenvolvimento de projetos de investigação-ação sobre a própria prática de ensino, no interior dos departamentos e faculdades, não aparecem como experiências de formação continuada. Essas iniciativas, valorizadas por muitos estudos, pressupõem que os departamentos propiciem um clima de reflexão coletiva sobre a prática docente e de apoio mútuo entre os professores visando à melhoria da qualidade do processo de ensino-aprendizagem.

Em especial nos programas de pós-graduação stricto sensu, os participantes consideraram que devem ser contemplados conteúdos referentes a didática, métodos e técnicas de ensino, práticas avaliativas, projeto pedagógico, embasamento filosófico e as bases teóricas e metodológicas da pesquisa. Esses conteúdos revelam que os participantes, estimulados a refletir sobre a formação da docência universitária, passaram a identificar saberes docentes específicos, que não têm sido contemplados em nenhum espaço formativo.

A ética foi sugerida como conteúdo da formação do professor universitário por apenas dois participantes. Tal fato pode indicar a ausência dessa temática na experiência vivenciada, importante 
tanto na prática da pesquisa quanto no exercício da docência universitária, principalmente se considerar que a docência é responsável pela formação de todos os outros profissionais. Incluir a ética profissional como componente da formação do professor universitário é compreendê-la não como algo dado, fruto do processo de socialização da pessoa do professor, mas, sim, como resultado de uma construção, baseada, essencialmente, na reflexão, na crítica e na confrontação de pontos de vista diferentes acerca de situações problemáticas significativas da prática profissional e de sua repercussão no contexto institucional, cultural, social e psicológico em que estão inseridas. (DESAULNIERS et al., 2003)

Só uma confrontação, na experiência, do sentido profundo de sua prática numa relação profissional particular poderá fazer emergir o questionamento sobre esta moral comum ou o temor às sanções. Assim, a tomada de consciência do sentido de sua prática, do ideal profissional e dos valores profissionais poderá se efetuar pelo reposicionamento do 'sujeito' numa relação profissional que implica um outro 'sujeito'. (DESAULNIERS et al., 2003, p. 210 - 211, tradução nossa $)^{6}$

Considerando que as lacunas também são reveladoras das representações, cabe destacar que determinados saberes e competências político-pedagógicos não foram referidos pelos participantes, tais como: aqueles relacionados ao contexto da prática pedagógica e do papel social da universidade e das políticas que envolvem essa instituição; a compreensão do contexto cultural e sócio-histórico dos estudantes que concorre para a construção do conhecimento articulada de forma autobiográfica; a ambiência

\footnotetext{
${ }^{6}$ Seule une confrontation dans l'expérience du sens profond de sa pratique dans une relation professionnelle particulière pourra faire émerger le questionnement sur cette morale commune ou la crainte des sanctions. C'est alors que la prise en compte du sens de sa pratique, de l'idéal professionnel et des valeurs professionnelles pourra s'effectuer par le repositionnement du 'sujet' dans une relation professionnelle impliquant un autre 'sujet'
} 
da aprendizagem, em especial, o conhecimento das condições de aprendizagem de pessoas adultas.

No que concerne às condições de aprendizagem de pessoas adultas, um respondente enfatizou a importância da sua experiência de docente na educação básica como preparação para o seu exercício na educação superior:

- Aprendi a ser professora, a dar aula no curso de magistério. $\mathrm{O}$ curso de magistério foi extremamente útil para atuar no $3^{\circ}$ grau (fala da estrutura da aula: motivação, aula propriamente dita e culminância). No $3^{\text {o }}$ grau continuo a fazer a mesma coisa. $\mathrm{O}$ que tem a mais é a capacidade de argumentação. A licenciatura que fiz não ensina a pessoa a ser professor, estava mais voltada para a pesquisa que para a sala de aula [...] Na universidade deveriam formar para a autonomia intelectual, de pensamento [...] Tento fazer isso, trabalhar a reflexão, mas não sinto que o ensino superior está voltado para isso, tem muita condução, pedagogia bancária [...] No ensino universitário devemos não só ter acesso a conteúdos, mas aprender a aplicá-los [...] Talvez devamos ter o foco no ensino, mas um ensino voltado para a pesquisa, para a indagação, construção de hipóteses etc. [...] o ensino superior é complexo, esta complexidade está em ter que dominar o conteúdo e saber transmitir este conteúdo [...] A tarefa de professor é semelhante, independente do nível, o que vai mudar são as atribuições.

O caráter interativo do trabalho docente e os desafios que ele engendra, também, não foram referidos nos depoimentos dos 
egressos, como elemento a ser considerado na formação do professor universitário. Esse aspecto, cada vez mais, é enfatizado nos estudos, por exemplo, de Altet (2001), quando afirma que o professor é um profissional da interação das significações partilhadas, ou seja, seu trabalho configura-se como uma vivência interativa, complexa e incerta, que requer uma série de tomadas de decisões imediatas, uma mobilização dos conhecimentos durante a ação e possíveis ajustes das ações previstas, de modo a adaptá-las a determinada classe ou a determinado tipo de estudantes (função didática e pedagógica).

Alguns participantes avançaram ao propor que a formação do professor universitário deveria incluir atividades que integrassem teoria e prática, cujo eixo seria a reflexão sobre a própria prática docente, na perspectiva de ampliação da sua capacidade de formar

- [...] indivíduos autônomos, criativos, solidários, que buscam, na ciência, na arte e na cultura, de modo geral, formas para compreender a si mesmos e ao mundo, compartilhando sentidos e construindo outros, sempre com vista à melhoria da qualidade de vida, como sugere um dos participantes.

A inclusão de atividades que articulem teoria e prática na formação do docente universitário é justificada pela ideia de que

- Não pode ser uma formação iluminista que dá ênfase aos conceitos. Refletir o exercício da prática. Se pensarmos em um currículo, ele deve garantir que o professor tenha espaço de encontro com seus pares (por exemplo, os de física) e com os outros (em educação), seminários sobre as experiências em grupos pequenos e grandes; a teoria é fundamental, 
subsidia o profissional [...] Se o mestrando já tem uma vivência em sala de aula (seja no ensino médio ou fundamental), talvez pudesse ter um ciclo de debates para que a prática pudesse ser avaliada. Para quem não tem essa vivência teria que pensar como fazer; $\mathrm{O}$ mestrado também deveria ter uma ou duas disciplinas e atividades voltadas para a metodologia do ensino superior para que a gente não reproduza os vícios da graduação. No dia a dia (do ensino) a gente não tem espaço para a discussão sobre as práticas e sobre a avaliação.

No processo de reflexão sobre a formação mais adequada ao professor universitário, emergiram críticas à formação vivenciada, que não foram referidas nas respostas escritas, em especial no que tange à metodologia do ensino superior, considerando que era um mestrado em educação, como atestam os depoimentos:

- A sensação é que o ensino não foi suficiente para a gente ser de fato professor competente na sala de aula. Saí com muitas carências. Desiludida um pouco com a área de educação. Os próprios profissionais que deveriam estar preparados para colocar em prática as teorias não conseguiam fazer isso.

- A utilização excessiva de seminários cujo formato esvaziava a aula, só ficava quem ia apresentar, quem ia avaliar e alguns poucos interessados no assunto. As aulas que tinham leitura coletiva eram mais participativas. 
- Faltou colocar todos nós em sala de aula no magistério superior e acompanhar nossa atuação.

Essas reflexões remetem à ideia defendida por diversos autores sobre a necessidade do isomorfismo, em outros termos, da congruência entre a formação profissional do professor e a formação que se espera que ele proporcione aos estudantes universitários.

\section{A regulamentação da docência universitária}

A formação do docente universitário, objeto deste estudo, remete à reflexão sobre a constituição de sua identidade profissional e, consequentemente, à regulamentação da docência universitária como profissão. Essa regulamentação pressupõe a formulação de elementos compartilhados na perspectiva de um ideal de prática profissional entendida como uma relação intersubjetiva. Esse ideal de prática profissional, no dizer de Desaulniers e outros (2003), é um horizonte de sentido que se redefine à luz das novas experiências das práticas, da transformação dos contextos institucionais e das pessoas que participam de sua definição e segundo a cultura na qual essas transformações se inscrevem. Implica a definição de normas a serem seguidas pelos profissionais e pelas instituições, com intuito de garantir a qualidade dos serviços prestados por esses profissionais e as condições essenciais para que essa qualidade seja assegurada. A regulamentação profissional interessa, ao mesmo tempo, aos profissionais, às instituições onde eles atuam e aos usuários dos serviços, no nosso caso, a população estudantil, que busca, na universidade, uma sólida formação profissional que habilite a sua inserção no mundo do trabalho.

Os participantes do nosso estudo parecem comungar com essa perspectiva quando assumem que a regulamentação possi- 
bilita ganhos para os professores (valorização e reconhecimento social) e para os estudantes (qualidade na sua formação).

Consideram que essa regulamentação deve contemplar aspectos como: formação proporcionando, aos professores universitários, o domínio de conteúdos essenciais à prática docente; aperfeiçoamento do processo seletivo desenvolvido pelas universidades públicas (relacionamento das disciplinas que pode ensinar com a graduação ou com a pós-graduação); direitos trabalhistas (no caso das instituições privadas) e direitos e deveres (no caso das instituições públicas, combate ao corporativismo etc.); definição de carga horária para ensino, pesquisa e extensão; plano de carreira; melhoria salarial.

A ética não aparece no rol de aspectos propostos para a regulamentação da profissão docente universitário, entretanto cabe destacar que, como registram Desaulniers e outros (2003), a exigência ética está no centro de toda relação de serviço, na medida em que uma pessoa pode tirar algum proveito indevido de outra ou, ainda, negar-lhe a realização de seus projetos. A prática do profissional professor universitário, como toda relação de serviço, é, essencialmente, relacional e intersubjetiva, o que implica a presença de conflitos de interesse, visões distintas sobre a qualidade do serviço, consequências sobre o outro etc. A exigência ética se configura como mais importante ainda quando se considera que essa relação intersubjetiva subentende, da parte do profissional, um compromisso de ajuda. Nesse sentido, o profissionalismo e a exigência ética passam a ser expressões sinônimas nas relações de serviço estabelecidas no interior das instituições educativas.

A construção de uma identidade profissional para o docente universitário pressupõe, no entender dos participantes, uma regulamentação que, para um deles, tem um papel relativo:

- Não creio em mudanças significativas e necessárias à sobrevivência da espécie humana por decretos. No entanto, acredito na força 
do coletivo movido pelo encontro de desejos. Sujeitos desejantes podem implementar as mudanças necessárias. E como nascem os desejos? O processo de formação de qualquer profissional se dá em todas as instâncias. A consciência da importância de seu trabalho, entender o movimento, a reflexão sobre a própria prática.

Esse depoimento remete a dois aspectos: 1) A regulamentação de uma nova identidade profissional dos professores universitários não pode se efetivar por decreto, ela pressupõe uma construção e reconstrução individual e coletiva e 2) A identidade profissional dos professores implica uma reflexão permanente sobre a prática. Analisando o primeiro aspecto, é interessante notar que, no contexto das profissões liberais clássicas, a identidade profissional era definida por adesão, pelo pertencimento a um grupo, a uma corporação com poder de supervisionar e punir as práticas consideradas inadequadas e desviantes do código estabelecido. No novo contexto social, marcado pelo crescimento da economia de serviços, a partir da implantação do Estado-de-Bem-Estar-Social, no qual os profissionais, em sua maioria, passaram a atuar em empresas privadas ou instituições públicas para prestar seus serviços à coletividade, é fundamental que a identidade profissional seja co-construída.

Entretanto, para coconstruir a identidade, é necessário haver um espaço de diálogo no qual uma prática pode ser questionada, aperfeiçoada e tornar-se uma prática significativa compartilhada. Com efeito, não é suficiente se inscrever numa ordem/associação profissional nem ocupar um emprego em uma instituição para que o sentido compartilhado seja adquirido. O espaço dialógico permite co-construir a identidade profissional ou institucional na qual é incorporado o sentido 
da prática. (DESAULNIERS et al., 2003, p. 195, tradução nossa $)^{7}$

Em síntese, a identidade profissional do professor universitário não pode se estabelecer de forma unilateral nem por decreto, como enfatiza o participante. Pressupõe uma co-construção no contexto das instituições universitárias visando a uma aproximação entre a identidade profissional e a identidade institucional, pois quanto menor for a distância entre essas duas identidades, maior é a chance de se assegurar um trabalho de qualidade. Assumir a identidade profissional implica, portanto, a integração dos valores pessoais, organizacionais e sociais. (DESAULNIERS et al., 2003)

O segundo aspecto emergente da fala desse participante de que a identidade profissional dos professores implica uma reflexão permanente sobre a prática é muito significativo, pois a identidade profissional se expressa na prática das pessoas, em outros termos, dos profissionais na condição de sujeitos concretos, individuais. A identidade profissional só funciona como baliza das práticas dos professores universitários se fizer sentido para cada "sujeito" profissional, o que significa dizer que a apropriação individual do sentido da sua prática, do papel social da instituição, da consciência do seu pertencimento é condição para que o "sujeito" se engaje conscientemente em práticas coletivas e contribua para a reconstrução permanente das normas que regulamentariam a profissão docente. Nesse sentido, como sugerem Desaulniers e outros (2003), diferentemente dos modos tradicionais de profissionalização, baseados na fusão ao grupo, o profissionalismo de serviço, no qual se inserem os docentes universitários, repousa, hoje, sobre o engajamento do profissional como sujeito. Assim, para que a "deontologia regulamentada" não funcione como mais

${ }^{7}$ Cependant, pour co-construire l'identité, il est nécessaire d'avoir un espace de dialogue dans lequel une pratique peut être remise en question, precisée et devenir une pratique significative partagée. En effet, il ne suffit plus de s'inscrire dans un ordre professionnel ni d'occuper un emploi dans une institution pour que le sens partagé soit un acquis. L'espace dialogique permet de co-construire l'identité professionnelle ou institutionnelle dans laquelle est incorporé le sens de la pratique. 
uma imposição do "nós" sobre o "eu", é fundamental a reflexão sobre a prática.

A reflexão sobre a prática, imprescindível para o engajamento consciente e protagonista do professor à deontologia regulamentada de uma identidade profissional do docente universitário, como sinalizado anteriormente, não implica o seu isolamento. Ao contrário, se nutre da relação dialógica com seus pares num processo de interpretação das normas num contexto social particular. Assim, quanto mais os docentes co-constroem os sentidos da sua profissão mais desenvolvem a reflexão subjetiva sobre sua prática, e vice-versa.

A análise do rico material oferecido pelos participantes relacionado à vivência no interior do Programa de Pós-Graduação em Educação coloca em relevo que esses programas não vêm assumindo, na prática, como parte dos seus objetivos, a formação do docente universitário. Focalizam, em contrapartida, a formação do pesquisador do campo educacional, em especial, da educação básica.

A experiência vivenciada pelos pós-graduandos com a investigação e a inter-relação entre teoria e prática contribuiu para ressignificar, em algum nível, as suas práticas educativas. Entretanto, a complexidade da docência universitária segue despercebida, o que naturalmente tem implicações diversas para a valorização do professor universitário que não atua nos programas de pósgraduação e desenvolve pesquisas e para os estudantes, futuros profissionais. Como os professores-coordenadores desses programas se posicionam sobre essas reflexões é o que veremos no capítulo seguinte. 



\section{Capítulo 5}





\section{Programas de pós-graduação em educação: o lugar da formação do professor universitário e os projetos pedagógicos em ação}

Os participantes, professores dos programas de pós-graduação em educação, que exercem ou exerceram a função de coordenação, forneceram importantes elementos para a compreensão do papel desses programas na formação do docente universitário. Seus depoimentos serviram de instrumentos para se explorarem as representações das comunidades acadêmicas desses programas sobre suas intencionalidades e compromissos com a formação de professores. Foram analisados levando-se em conta os seguintes aspectos: os objetivos da pós-graduação stricto sensu; o papel específico da pós-graduação em educação; a contribuição do programa de educação para a formação do professor universitário; a concepção de docência universitária; o lugar da formação do docente universitário; a avaliação da CAPES frente à dimensão pedagógica como função da pós-graduação. 


\section{Objetivos da pós-graduação stricto sensu}

A formação de quadros com nível elevado para produzir conhecimento, como estabelece a CAPES, aparece como o principal objetivo dos programas de pós-graduação stricto sensu no Brasil, na visão dos participantes, como ilustra o depoimento de um dos coordenadores do PPGE2: “- [...] a CAPES define como autonomia a realização da pesquisa e da produção do conhecimento; não traduz isso em sala de aula, na verdade."

Além da formação para a pesquisa, entretanto, alguns participantes consideram que também é objetivo desses programas a formação do docente universitário. Na visão de um dos depoentes do PPGE1, essa formação parece se verificar mais em função das demandas do mercado do que de uma ação intencional do sistema. Diz que

- [...] a despeito do objetivo de formação de pesquisadores, na prática os Programas acabam cumprindo mais uma função de formação de profissionais com alto nível de qualificação para atuarem, não só em pesquisa, mas em ensino. Grande parte dos pós-graduados acaba não se dedicando à pesquisa, boa parte acaba atuando exclusivamente no ensino e uma parte dependendo da área vai para atuação no mercado.

Esse depoimento suscita algumas questões e nos faz indagar: dado o destino profissional da maioria dos egressos desses programas, significa, efetivamente, que a pós-graduação está assumindo a formação específica do profissional professor universitário? Ademais, reconhecer que a educação superior é o destino da maioria dos egressos dos programas de pós-graduação stricto sensu, como registra o depoente, não deveria desafiar seus coordenadores a 
promover uma reflexão constante sobre o caráter dessa formação tendo em vista a docência universitária?

Embora considerando que a formação do docente universitário é um dos focos dos programas de pós-graduação stricto sensu, segundo um dos coordenadores do PPGE2, as políticas de pós-graduação no país têm encaminhado quase unicamente para a formação de pesquisadores: "-Hoje é difícil discriminarmos com muita nitidez o que significa uma formação de mestrado e de doutorado, pois ambas têm ênfase na pesquisa." Não há, claramente, a concepção de formação para a docência como intencionalidade. Essa posição decorre, certamente, da crise de legitimidade que os conhecimentos pedagógicos para a docência da educação superior se manifesta mesmo num programa que tem esses conhecimentos como fundantes. Os programas de educação, regidos pelas mesmas políticas dos programas de pós-graduação das demais áreas, respondem, de maneira semelhante a esses, sem uma reflexão própria sobre o papel que poderiam assumir no campo da formação de professores da educação superior.

\section{O papel específico da pós-graduação em educação}

Quando instados a falar sobre o papel específico que a pósgraduação stricto sensu em educação desempenha no conjunto do sistema de pós-graduação, os respondentes deixam emergir duas percepções. A mais evidente defende que a especificidade desses programas é contribuir para formar o pesquisador na área de educação. Um dos parceiros do estudo afirma (PPGE2):

- O Programa de Pós-Graduação em Educação mantém a sua especificidade, porque, ainda que dê pouca ênfase à formação de profissionais para os processos educativos, que implicam aprender e ensinar, há, sim, uma 
especificidade garantida no sentido que no outro eixo, o eixo da formação do pesquisador, é o pesquisador para a área da educação que interessa. De qualquer modo se preparam profissionais para conhecer melhor, ter melhores argumentos para questionar determinadas políticas educacionais, produzir conhecimento etc.

Complementando, um coordenador do PPGE1 considera que

- [...] pretensamente a pós-graduação em educação está aberta à formação de pósgraduados, stricto sensu, das mais diversas áreas e, muitas vezes, os profissionais que vêm de outras áreas têm um objetivo de trabalho muito específico e acabam não recebendo uma formação efetiva para o ensino. Muitas vezes já têm experiência em ensino de $3^{\text {o }}$ grau, então acabam não fazendo TD (Tirocínio Docente) e o estágio orientado. Escolhem uma temática de pesquisa que tem pouca relação com a prática docente e passam por aqui quase sem mudar significativamente seu repertório relativo a ela.

Esse depoimento é relevante, pois induz a conclusão de que a falta de uma intencionalidade do programa em relação à formação do docente universitário, expressa em conteúdos e práticas curriculares, contribui para descaracterizar essa especificidade no contexto dos programas de educação. 


\section{A contribuição do programa de educação para a formação do professor universitário}

No que tange à contribuição do programa em que atuam para a formação do professor universitário, o testemunho dos participantes aborda aspectos referentes a como o programa lida com as expectativas dos pós-graduandos que vêm de áreas diversas; que contribuição o programa tem dado para a formação do docente universitário; e quais as iniciativas de acompanhamento dos egressos e avaliação do impacto da formação nas suas práticas educativas no ensino superior.

Em se tratando de como o programa lida com as expectativas dos pós-graduandos oriundos de áreas diversas - muitos atuam como professores do ensino superior -, os coordenadores revelam que essas expectativas são analisadas, principalmente, no processo de seleção. Em geral, quando se referem às expectativas dos candidatos aos programas, revelam, especificamente, os objetos de pesquisa contidos nos projetos apresentados para a seleção. É interessante destacar que não entra na agenda da seleção a existência de expectativas relacionadas ao desenvolvimento das suas competências como professores do ensino superior.

Assim, embora a condição de professor universitário, em especial das universidades estaduais, assegure uma pontuação a mais na análise de currículo, desde que aprovado na etapa da seleção de prova de conteúdo, no PPGE2, não há uma determinação institucional de contemplar as expectativas dos pós-graduandos, nem mesmo daqueles que vêm de áreas distintas da de pedagogia, relacionadas à formação para a docência universitária, como afirma um dos depoentes:

- Os pós-graduandos oriundos de áreas diversas, no Programa [...] não são contemplados de forma diferenciada, eles entram no geral, 
vai variar de orientador, [...] tentar articular o projeto de pesquisa que a pessoa está trazendo, com a linha de pesquisa que o professor está desenvolvendo e com a atuação como docente em uma dada instituição. Imagino que alguns professores devem cuidar muito desse entrelaçamento e outros ficam mais voltados para o projeto em si. Interessante essa colocação, pensar no Programa, a pertinência e a importância do olhar para esse mestrando aliando a sua dimensão como docente, podia ser um elemento inovador do programa.

A atenção às expectativas apenas quando são expressas nos projetos de pesquisa também se verifica nos depoimentos dos coordenadores do PPGE1:

- A gente acolhe e valoriza, mas com muita atenção, para não perder a identidade do campo educacional. As questões dos objetos educacionais, por mais plurais que sejam, acabam não sendo garantidas e aí se perde uma certa alteridade, que é pensar o campo educacional... uma identidade que parte de uma alteridade da diferença.

- As expectativas deles são consideradas. A gente tem um processo de seleção complexo que passa por análise de memorial, por entrevista, a entrevista é feita pela linha. Cada linha tem suas regras internas, vai ouvi-lo através do seu projeto, da sua entrevista, então o processo seletivo já é uma forma de ouvir essas demandas. Agora, durante o desenvolvimento da proposta do Programa isso fica basicamen- 
te com o orientador, porque é ele que define as disciplinas que vão ser cursadas. Ele que recomenda os nomes dos membros da banca de qualificação considerando os critérios do colegiado, então tanto o direcionamento da formação quanto a capacidade de ouvir suas expectativas fica fortemente concentrada na mão do orientador.

Desperta curiosidade a ausência de atenção acerca das motivações dos candidatos e dos pós-graduandos, muitos deles docentes universitários de outras áreas, para a escolha de um Programa de Pós-Graduação em Educação e o fato de a análise das motivações se restringir aos projetos de pesquisa, que em geral não revelam a busca de saberes pedagógicos para o ensino superior em função da inexistência de linhas e grupos de pesquisa consolidados nos programas sobre a pedagogia universitária. Essa postura parece estar coerente com a perspectiva da centralidade da formação do pesquisador em detrimento da formação do docente.

Analisando a contribuição do programa de educação, em que atuam, para a formação do professor universitário, os coordenadores do PPGE2 afirmam que ela efetivamente não existe, pois o programa está fortemente

- [...] centrado no conteúdo, no objeto de estudo que ele (pós-graduando) quer analisar. Provavelmente ele ficou mais seguro no conteúdo, na transmissão da sua disciplina, ou até mudou de disciplina, mas não temos nenhuma possibilidade de fazer uma hipótese acerca de como ele está se saindo em termos de um professor para o ensino superior.

A esse respeito, o depoimento do outro membro do PPGE2 revela que o Programa tem priorizado responder às exigências 
do Sistema Nacional de Pós-Graduação, que, em sua opinião, não valoriza a formação do professor universitário. Entretanto, registra que

- [...] começamos um trabalho inicial em relação ao TD. Começamos com o TD restrito aos bolsistas depois tornamos obrigatório para todos os alunos, salvo aqueles que já estão ou tiveram em período recente a experiência de exercício docente. Estamos tentando fazer isso sem abalar a posição de pontuação, de qualificação no sistema.

Os coordenadores do PPGE1 entendem que a dimensão da formação do docente universitário é assumida no programa, embora com limitações. Um deles afirma:

- Temos um conjunto de disciplinas que possibilitam a esse professor fazer esse caminho, disciplinas ligadas a metodologias, a pensar o objeto da didática, temos grupos de pesquisa que se interessam por isso. Os debates são transversalizados, sim, pela questão da formação do professor em todas as disciplinas. A pesquisa e a formação do professor são duas grandes transversalidades aqui. Obviamente a gente não faz um debate específico sobre formação de professor universitário. Eu acho até que está faltando [...] um debate específico sobre sua formação [...], mas como transversalidade existe. Mas eu gostaria que fosse além da transversalidade.

Acrescenta que a "- [...] formação do professor universitário deveria ser uma centralidade e não transversalidade [...]" já po- 
deria estar sistematizada em nível de componentes curriculares capazes de propiciar essa formação.

Esse coordenador reforça seu ponto de vista, evidenciando, na sua prática como docente no programa, a existência de espaços para a formação desse professor:

- O tempo todo procuro que os problemas das práticas encontrem espaços. Se a gente deixar ficam o tempo contando a história de suas práticas [...] eu concordo que não há espaço específico. Todos nós somos obrigados a pensar a questão da pesquisa e do método e não só as disciplinas de metodologia de pesquisa. Também todas as disciplinas acabam discutindo essas práticas, o problema é que as pessoas não formulam [...] As pessoas pensam que o exemplo que ela deu não é reflexão sobre sua própria prática, as pessoas não assumem a discussão sobre as práticas como reflexão sobre a própria prática [...] Tem sim espaço, e muito espaço, mas não está garantida uma reflexão mais formulada. Eu sou a favor de um componente curricular, tal a centralidade da formação do professor.

Outra contribuição do programa para a formação do professor universitário é registrada por este depoente do PPGE1:

- Uma das coisas que nós fizemos durante nossa gestão foi discutir a mudança curricular do Programa. Era um Programa que engessava a autonomia do aluno, um aluno adulto, ele passava o tempo todo aqui fazendo disciplina amarrada a núcleo, amarrado a linha [...] 
Fizemos hoje um Programa enxuto, responsável, que garante disciplinas que dão acesso ao conhecimento específico da nossa área de concentração, entretanto, a grande parte da vida do aluno de mestrado e doutorado é feita pela gestão do aluno com seu professor orientador, com o Programa disponibilizando as condições curriculares para tal.

Esses elementos, embora importantes porque asseguram um maior protagonismo ao pós-graduando na gestão da sua formação, em parceria com seu orientador, não alteram a lógica da exclusividade do ponto de vista curricular da formação para a pesquisa em detrimento da formação para a docência.

A ausência de reflexão sobre as mudanças necessárias para que a formação do docente universitário seja assumida de "forma excelente" é registrada por um dos depoentes do PPGE1. Ele afirma que a prioridade da coordenação tem sido resolver "- [...] os problemas estruturais que estavam colocando em risco a vida do programa $[. . .]^{\prime \prime}$, como recredenciamento docente, mudança do regimento, aumento de produtividade. Acrescenta que só num segundo momento será possível pensar em medidas capazes de dinamizar essa formação, como o

- [...] acompanhamento do trabalho docente em sala de aula, um controle social mais significativo das disciplinas ofertadas, aumento do leque de disciplinas, inclusive para buscar uma formação didática mais significativa.

Esse coordenador do PPGE1 reconhece que a formação do docente é assumida

- [...] porque existem instrumentos legais que obrigam que a gente faça, é preciso ter tiro- 
cínio docente, estágio orientado, o bolsista é obrigado pela CAPES a fazer estágio orientado docente, os demais já trazem experiência universitária.

Os depoimentos apresentados indicam que a preocupação em ser bem classificado pela CAPES, como agência de avaliação e de financiamento, tem concentrado a atenção dos gestores dos Programas em responder as suas exigências, colocando, em segundo plano, a autonomia e a busca de especificidade na perspectiva de atender as demandas consideradas pertinentes dos contextos onde estão inseridos, embora o Parecer 977/65 (BRASIL, 1965) estabeleça que a

[...] estruturação dos cursos pode sofrer variações em função das peculiaridades de cada setor de conhecimento e da margem de iniciativa que se deve atribuir à instituição e ao próprio aluno na organização de seus estudos.

Essa condição atende o conceito de sistema, que tem as suas vantagens no contexto nacional, mas, muitas vezes, exaure as energias que deveriam ser postas, com mais autonomia, nos projetos pedagógicos de cada programa.

Os coordenadores também afirmaram serem raras as iniciativas de acompanhamento dos egressos, especialmente quanto à repercussão da formação na sua atuação como docentes universitários. Um dos coordenadores do PPGE1 avalia:

- Não, não existe nenhum trabalho de acompanhamento dos egressos, eles são grandes desconhecidos para nós, um erro grave em termos curriculares, que continua sendo um artefato fundamental do professor universitário. Ele poderia contribuir para que o currículo não fosse um ato hermafrodito da 
própria instituição, no qual os professores se reúnem e decidem o que é bom para os alunos.

Esse acompanhamento, conforme outro coordenador do PPGE1, passou a ser uma necessidade diante da recomendação de inclusão do egresso no Coleta de Dados CAPES e, consequentemente, da sua pontuação no processo de avaliação dos programas. Convém destacar que os aspectos contemplados no cadastro dos discentes do relatório Coleta de Dados CAPES se referem à pesquisa e à produção científica, e não à atuação na docência universitária. É provável que a valorização do quesito "Impacto Social", no contexto da avaliação, possa induzir a ampliação dessa dimensão.

O participante ressalta que essa é uma preocupação da sua gestão:

- No último ano fizemos de uma maneira sistemática, mas não censitária, um trabalho de acompanhamento de egressos recentes, para constar do nosso relatório e para pensarmos um pouco se estamos cumprindo nossa função institucional. Mas a nossa ideia é ter um sistema de acompanhamento amplo e tentar recuperar essa memória dos egressos, onde estão, o que estão fazendo, o impacto que causou, fazer entrevista. Isso está na ordem do dia.

O cadastro do discente proposto pela CAPES, embora seja alimentado de forma incipiente por falta de infraestrutura e de pessoal, é considerado como um importante instrumento por um dos coordenadores do PPGE2, pois "- [...] dá a condição de um acompanhamento mais de perto." 
O mesmo depoente acrescenta,

- [...] precisamos estabelecer, mesmo, uma política do Programa de estar junto a esses egressos [...] Falta um diálogo mais permanente, uma rede de acompanhamento, seria um bom caminho para o programa.

\section{A concepção de docência universitária}

Subjacentes à reflexão sobre a contribuição dos respectivos programas para a formação do professor universitário estiveram as concepções de docência universitária dos participantes. Convidados a expressar essas concepções, emergiram declarações como "o professor pesquisador", envolve o domínio de saberes do campo educacional, "inexistência de distinção fundamental entre professor da escola básica e professor universitário." Ademais, entre as concepções estão "ser formador da cidadania mais do que do profissional e "é uma profissão assistida."

A competência para fazer pesquisa é o atributo do docente universitário unanimemente referido pelos participantes, como ilustra o depoimento abaixo de um dos coordenadores PPGE2:

- [...] todo professor universitário deve ser pesquisador [...] a metodologia do ensino superior implica você incluir a pesquisa e a extensão; não há como você ensinar metodologia do ensino superior apenas com o ensino, porque a pesquisa é justamente você viabilizar o hábito de duvidar do que está falando, não é só transmissão. O ensino, basicamente, é transmissão, enquanto que a pesquisa é produção. 
A inclusão da pesquisa na docência universitária, para esse respondente, se justifica na medida em que esse nível de ensino tem como tarefa central desenvolver a autonomia e a capacidade de reflexão e crítica com vistas à transformação da realidade: “- A reflexão sobre seu entorno e a informação apenas não fazem isso, o que faz é você sair, pesquisar, consultar as pessoas da comunidade $[\ldots]^{\prime \prime}$

Entretanto, acrescenta que a inclusão da pesquisa na docência universitária é um grande desafio, pois assumir um ensino centrado no questionamento do estudante, direcionado "[...] para a busca de respostas [...] requer uma humildade muito grande, então o professor prefere ficar com o ensino, ele não quer trabalhar uma docência que implique pesquisa."

Um dos coordenadores do PPGE1 ressalta que sua concepção de pesquisa vai muito além de uma ética produtivista de conhecimento:

- [...] envolve uma ética de formação do professor, via os princípios, o ethos, a ética da pesquisa e seu comprometimento político, quer dizer não é só produzir uma tese, produzir pesquisa, portanto, a pesquisa como algo fundante.

A ênfase atribuída pelo conjunto dos participantes à pesquisa, como característica da docência universitária, corrobora com a visão de Ambrósio (2001, p. 94), que concebe a pesquisa como meio privilegiado de:

[...] desenvolvimento do sujeito \aluno, desenvolvimento intelectual, cultural, científico, pessoal, alcançado através da aquisição de conhecimentos científicos e tecnológicos, de capacidades de problematização ou resolução de problemas, de capacidades de reflexão analítica e crítica, de ca- 
pacidade de gestão e de criação de conhecimentos e saberes e de mobilização de competências.

A adoção da investigação como fio condutor do processo formativo na universidade, além de possibilitar o desenvolvimento da autonomia dos estudantes, permite que o professor assuma [...] perante os alunos, a atitude humilde de quem não sabe e está consciente de que anda à procura e convida os alunos a participar dessa mesma tarefa (DIAS, 2001, p. 70), fundamental para o processo de construção compartilhada do conhecimento.

A concepção de docente universitário, como pesquisador, implica o acolhimento dos estudantes como parceiros, 'candidatos à investigação' e na constituição de uma comunidade de aprendizagem na qual se desenvolve a 'aventura da pesquisa' contribuindo para o crescimento pessoal de cada um e para a formação de profissionais críticos e investigadores da sua realidade e de suas próprias práticas. (DIAS, 2001)

Entretanto, é um equívoco pensar que os saberes da pesquisa se transferem mecanicamente para os saberes do ensino. A pesquisa, embora fundamental no processo formativo, não é suficiente para assegurar a qualidade da docência universitária. Essa relação exige saberes do campo pedagógico, indispensáveis para a mediação entre o ensino e a pesquisa, como registram diversos autores já referidos. Um dos coordenadores do PPGE2 é enfático quanto a essa questão, ao dizer que a “- [...] formação do professor universitário deve também envolver a pesquisa, mas não pode atribuir essa primazia em detrimento da formação docente."

Todavia, a concepção de docência como portadora de saberes do campo educacional, embora sinalizada pela maioria, parece estar mais distante das reflexões do cotidiano dos participantes, pois os depoimentos não revelam elementos mais concretos, não indicam quais são esses saberes. Configuram-se, portanto, em 
formulações de teor genérico. Serve de exemplo o depoimento de um membro do PPGE1:

- [...] o trabalho docente é basicamente o de professar ideias, o que pressupõe a capacidade de fazer a transformação didática, de permitir que o aluno saia do ponto que está para o ponto que se quer chegar. Depende, também, de saberes específicos que não são os saberes das áreas, não é o saber do contador, do matemático, do engenheiro. Essa capacidade didática pode ser desenvolvida num trabalho sistemático na educação. Infelizmente, parte significativa dos cursos de pedagogia e dos programas de pós-graduação em educação não considera muito fortemente essa formação didática.

A parte inicial dessa formulação sugere um entendimento dos saberes do campo educacional, principalmente, associados às técnicas de ensino. Como sinalizamos anteriormente, além dos saberes e ações de ordem técnica visando à combinação eficaz dos conteúdos, dos meios e dos objetivos educacionais, diversos outros aspectos constituem os saberes do campo educacional dos quais o docente universitário precisa se apropriar, como saberes e ações de natureza afetiva que aproximam o ensino de um processo de desenvolvimento pessoal; saberes e ações de caráter ético e político, sintonizados com uma visão de ser humano, de cidadão e de sociedade; saberes e ações voltados para a construção de valores considerados fundamentais; saberes e ações relativos à interação social, ao conhecimento mútuo, à recomposição de suas memórias educativas, que revelam a natureza profundamente social do trabalho educativo e favorecem a co-construção da realidade de forma autobiográfica. 
A subestimação dos saberes pedagógicos, referida por esse participante do PPGE1, é atribuída ao fato

- [...] da pós-graduação (em educação) ter sido formada no período de ditadura, ter tido um papel crítico, tudo isso faz com que a gente tenha um discurso muito crítico, isto é positivo, mas, por outro lado, isso acabou se fortalecendo muito em detrimento de um trabalho, que é trabalho político também, mas de outra natureza, político no sentido da capacidade de tomada de decisão numa situação de sala de aula para que essa relação didática, esse trabalho didático ocorra, isso a gente não tem valorizado muito.

Essa subestimação, ao que tudo indica, tem relação com, pelo menos, dois modelos de docente universitário, que não são mutuamente excludentes: o tradicional, porta-voz de um saber dogmatizado, capaz de transferir, mediante o dom da oratória em aulas magistrais, seus saberes profissionais, sendo para tanto exigido apenas o domínio de conteúdos específicos de sua área de conhecimento, sem a preocupação de conhecer os estudantes e possibilitar-lhes uma aprendizagem significativa; e o pesquisador, preocupado, essencialmente, com a produção de conhecimento, tarefa considerada como primordial e mais nobre da universidade. A supervalorização da atividade de pesquisa contribui para a percepção dos professores de que investir em inovações no desenvolvimento da docência é algo que implica muito desgaste pessoal, como registram Gros Salvat e Romañá Blay (2004).

O desprestígio dos saberes pedagógicos que prevalece na universidade pode estar também associado à representação social dos professores acerca do campo da pedagogia, que remete à infância. Representações que guardam relação com a origem da palavra pedagogia, que deriva do grego paidagogos, que significa "guia de 
crianças", educador, e de paidagogiké (techne), que significa arte de condução das crianças, expressão que, ao longo do uso, ganhou o sentido mais geral de arte ou de doutrina da educação.

A representação dos professores sobre a pedagogia se tece também num contexto em que a formação do educador de crianças, só muito recentemente, a partir da Lei de Diretrizes e Bases da Educação Nacional N 9.324/96, é assumida pela universidade, e a formação do professor para o ensino secundário, que sempre se desenvolveu na universidade, historicamente adotou o modelo do bacharelado fortemente centrado nas disciplinas específicas de cada campo do conhecimento e, secundariamente, no último período, algumas disciplinas relacionadas à didática e à prática educativa, configurando o criticado modelo 3+1, que prevalece até hoje. Esses dados indicam que, mesmo para os níveis anteriores ao universitário, os saberes pedagógicos não eram legitimados e aprofundados na academia.

Como afirma Cunha (2008), foi no governo dos militares (1964-1982) com a criação das Faculdades de Educação, que esse campo de conhecimento, paradoxalmente, se instalou na academia. As Faculdades de Educação integravam o conjunto de medidas expressas na Lei da Reforma Universitária, em substituição às extintas Faculdades de Filosofia, Ciências e Letras, na tentativa de esvaziar a posição crítica e política dessas unidades. Os saberes pedagógicos foram assumidos pelas Faculdades de Educação numa perspectiva preponderantemente tecnicista e instrumental, fundada na lógica da neutralidade da educação, segundo a qual os meios tomaram caráter preponderante sobre os fins. Assim, a pedagogia se configurava com uma natureza pragmática, relacionada mais a receitas e técnicas aplicáveis de forma geral às situações de sala de aula. Nesse sentido, não se justificava a constituição de um campo científico próprio, que se ocupasse de seu objeto. Esse ideário, que teve forte repercussão, suscitando, em especial após o fim da ditadura, muitos embates no interior dessas faculdades para sua superação, parece ressurgir no contexto neoliberal para 
responder às exigências do mercado, principalmente com os parâmetros da qualidade total e a pedagogia das competências.

A pedagogia, como campo de estudo, não apresenta objeto único, mesmo tendo uma estrutura epistemológica básica. A sua aplicação nos diversos ciclos do desenvolvimento humano dá origem a diversos recortes de estudo, determinando a assunção de várias pedagogias - pedagogia da infância e da adolescência, como exemplo, ou etapas formais de ensino, como educação infantil (pré-escola), séries iniciais, ensino médio etc., e a pedagogia universitária -, assentadas em conhecimentos singulares. Esse novo contexto questiona o modelo tradicional do professor universitário erudito, porta-voz de um saber dogmatizado, destituído de saberes pedagógicos que lhe permitiriam contribuir para a realização de aprendizagens significativas pelos estudantes. Evidencia a complexidade da docência e a necessidade de fortalecimento do campo da pedagogia universitária.

Essa reflexão sinaliza um frágil reconhecimento da especificidade da docência universitária, que parece estar subjacente ao depoimento de um coordenador do PPGE:

- Eu acho que não deveria ter uma diferença muito significativa em termos de postura entre o professor da educação básica e universitária. É uma questão de experiência, de maturidade, uma questão de especialidade, uma questão de foco de pesquisa. Eu acho que tanto o professor universitário quanto o da educação básica deveriam incentivar a autonomia, capacidade de investigação, reflexão crítica sobre a realidade, ao mesmo tempo em que possibilitassem condições de acesso ao conhecimento já produzido, disponibilizado e às formas de utilização na sociedade do conhecimento. 
A pedagogia universitária se distingue da pedagogia em geral por seu interesse em compreender o processo de aprendizagem das pessoas adultas na sua trajetória de formação profissional. A educação de adultos implica, portanto, a consideração de determinados princípios, entre os quais, o engajamento consciente e voluntário do estudante no processo de aprendizagem, a negociação de todos os aspectos referentes a esse processo, a valorização da busca de solução de problemas da prática como foco do ensino e da abordagem das teorias. Esses princípios implicam a superação da dualidade professor e estudantes e a configuração de um contexto de encontro entre adultos que se engajam solidariamente para encontrar respostas para os problemas e vivenciar um processo complexo de formação de pessoas, cidadãos e profissionais críticos e reflexivos.

A ausência de tratamento condizente com a condição de adulto dos estudantes universitários parece ainda predominante. Soares (2008) encontrou, entre professores universitários, o recurso a diversos mecanismos de controle unilateral com o objetivo de envolver os estudantes no processo de ensino-aprendizagem. Vale citar, por exemplo, a redução de ponto na "nota" do estudante, cujo nome houvera sido sorteado, no início de cada aula para fazer a apresentação oral, mas que não o fez por não ter estudado o assunto. A adoção desse tipo de mecanismo de controle do processo educativo, além de sinalizar a orientação curricular excessivamente conteudista, que negligencia a reflexão sobre as atitudes e os valores, que priva o estudante do conhecimento sobre si mesmo no processo da convivência e da troca, revela uma visão infantilizadora dos estudantes, que naturaliza a heteronomia e os faz crer que não merecem confiança, não são capazes de fazer opções autônomas.

A experiência no contexto universitário permite afirmar que é comum encontrar professores que encaram os estudantes como adultos, numa perspectiva diferente da anteriormente apontada, ao alegarem que, na universidade, os estudantes já deveriam 
saber o que querem. A expectativa é que eles sejam dedicados e comprometidos com sua aprendizagem, o que justificaria a falta de empenho do professor em compreender as condições reais, em ajudá-los a encontrar o sentido dos conteúdos ensinados para sua vida e sua futura profissão. Esses professores não se veem como artífices, junto com os estudantes, de estratégias que favoreçam aprendizagens significativas, ancoradas nas suas estruturas culturais, afetivas e cognitivas.

A docência universitária aparece, também, como decrescentemente responsável pela formação profissional e, principalmente, pela formação para a cidadania, formação anteriormente atribuída, na percepção de um dos participantes do PPGE1, à escola básica. Tal visão é explicada pelo fato de o ensino superior ter deixado de ser terminal em função da ampliação do acervo de conhecimento disponível na atualidade e da capacidade de sua produção e da mudança de compreensão do papel do conhecimento na sociedade.

- Com essa mudança, e com um papel cada vez maior da educação continuada, seja lato ou stricto sensu, ou através dos cursos de aperfeiçoamento, o ensino superior, de certa maneira, tem se constituído cada vez mais num elemento de formação da cidadania, muito mais forte que de formação profissional [...] Esse tempo de formação se tornou insuficiente, para conseguir que esse profissional chegue em condições de dar conta das exigências colocadas pela sociedade e pelo mercado, isso faz com que o ensino superior se torne cada vez mais uma passagem.

A ampliação do volume de conhecimentos na atualidade e da capacidade de sua produção e difusão é um fato que segu- 
ramente impacta os processos de ensino e de aprendizagem na universidade. Entretanto, essa ampliação não parece implicar a descaracterização da graduação como lócus da formação profissional. Esse argumento poderia, igualmente, implicar a dificuldade de o mestrado assumir esse papel. O desafio que está posto para a universidade e que se acentua nesse novo contexto é o de transformar o ensino conteudista, baseado na transmissão fragmentada, dogmática e desarticulada do contexto social, na perspectiva de um processo formativo centrado na indagação, na reflexão crítica da realidade, na investigação da prática profissional à luz das bases epistemológicas, políticas, culturais dos conteúdos. Precisa possibilitar aos estudantes aprenderem a aprender ou, no dizer de McLaren (2003 apud VIEIRA, 2005, p. 14), aprofundarem “[...] a compreensão de si próprios, do mundo, e das possibilidades de transformação dos pressupostos tacitamente aceitos acerca do modo como vivemos."

O enfrentamento de tal desafio pressupõe, por parte dos docentes universitários, em primeiro lugar, uma profunda reflexão acerca da concepção de profissional a ser formado e a identificação de formas de resistência às pressões pela mercantilização da cultura e das práticas acadêmicas, pois, como nos alerta Naidoo (2008), a subordinação da universidade aos princípios do mercado pode obstruir a inovação, fomentar atitudes passivas, acríticas e instrumentais no processo de aprendizagem e no exercício profissional.

Ainda, é necessário assumir a pedagogia universitária e as práticas educativas como objeto de investigação, indagando seus sentidos, pressupostos, implicações, crenças e concepções de ensino, aprendizagem, avaliação e formação. Fundamental se torna tecer articulações entre teoria e histórias de vida, entre conhecimentos, práticas e afetos, geradoras de uma práxis emancipatória e potencializadora da construção de subjetividades protagonistas, éticas e socialmente comprometidas. 
A docência, na visão de um dos participantes do PPGE2, deveria ser concebida como uma profissão "assistida", em analogia aos psicanalistas, o que significa que o professor

- [...] precisa recorrer a outros profissionais, que ele não deveria ser colocado num ambiente de ensino sem ter um grupo de referência no qual pudesse refletir sobre essa experiência com outros profissionais, coordenadores, independente do nível de atuação, da escola à universidade.

Essa perspectiva é muito interessante e implica mudanças profundas na própria cultura do trabalho docente, fortemente individualista, retirando o ensino universitário do domínio privado das quatro paredes da sala de aula. Remete à profissionalização do professor universitário, isto é, a um processo coletivo de desenvolvimento de capacidades e de formalização dos saberes implementados na prática profissional que culmina na profissionalidade, entendida como o conjunto de atitudes, valores, comportamentos, destrezas, conhecimentos, saberes, estratégias construídas e reconstruídas de forma permanente e coletiva pelos profissionais.

Esse processo coletivo de construção da identidade e da profissionalidade do docente universitário, como sugere o participante, não pode prescindir do engajamento pessoal do profissional aos saberes e práticas compartilhados, capazes de dar um horizonte ao profissionalismo (que significa o exercício com competência e ética da prática profissional, de forma a garantir o prestígio social da profissão). Precisa fazer sentido para cada sujeito e ter como centro a reflexão sobre as próprias práticas; as justificativas de suas escolhas, que têm raízes nas dimensões subjetiva, histórica, cultural e política, configuram o ato pedagógico como um amálgama complexo; e a articulação com as produções teóricas 
do campo das ciências da educação na perspectiva de fortalecer a capacidade de reflexão do professor, como um profissional capaz de trabalhar com os argumentos de racionalidade, próprios de quem tem consciência de seus projetos e ações.

A concepção de profissão "assistida" pelos pares se justifica, na compreensão desse participante,

- [...] em função de que o vínculo do professor com o assunto de uma disciplina tem uma carga de conhecimento que tem a ver com o nível cognitivo, mas tem uma carga afetiva também. Possui uma carga que tem a ver com o valor social, existem disciplinas mais ou menos valorizadas socialmente, professores mais ou menos valorizados socialmente, disciplinas que o professor gosta mais ou menos, disciplinas que o aluno gosta mais ou menos. Tem uma série de implicações em relação a esse objeto de trabalho, portanto, se este vínculo não for trabalhado pode interferir de uma forma muito complicada na relação do professor com o próprio assunto. Também na sua forma de lidar com esse conhecimento junto ao aluno, na relação do aluno com esse conhecimento. Essa profissão deveria ser permanentemente assistida por grupos de referência qualificados.

A perspectiva apresentada enfatiza as implicações da relação do professor com o conhecimento. Entretanto, o caráter "assistido" se justifica, também, pelo fato de a prática do profissional do professor universitário ser, essencialmente, relacional e intersubjetiva, o que implica a presença de conflitos de interesse, visões distintas sobre a qualidade do serviço, de suas consequências sobre o outro etc., o que coloca fortemente a exigência ética. 


\section{O lugar da formação do docente universitário}

Solicitados a falar sobre o lugar mais apropriado para a formação do professor da educação superior, os coordenadores reafirmam que, em princípio, a universidade se constitui nesse lugar, em função da sua perspectiva de articulação entre ensino, pesquisa e extensão. Entretanto, as proposições vão se tecendo num processo de idas e vindas, como se tateando num terreno ainda nebuloso. Por ser difícil, para os participantes, sugerirem uma proposta de lugar, apresentam um leque de possibilidades. Pode envolver a graduação e a pós-graduação, tanto lato quanto stricto sensu, acadêmica ou profissional, pelo que se infere do depoimento de um dos coordenadores do PPGE1.

- A princípio, teríamos que pensar numa formação pós-graduada, de preferência stricto sensu, porque a formação lato sensu, embora tenha um papel importante do ponto de vista profissional, não é avaliada, não é feita de maneira sistemática. Acho que a formação stricto sensu poderia ter um papel mais significativo nisso, mas ainda não tem. Quem consegue cumprir esse papel, em certa medida, é a formação lato sensu, quando direcionada especificamente e contando com bom planejamento, profissionais adequados. Mas ela é muito irregular, varia muito de instituição, de área, algumas acabam cumprindo, mas não de forma larga.

Considerando que reconhecem a pesquisa como base dessa formação, tendem a propor que ela se dê nos programas de pósgraduação. Apesar de, anteriormente, ter afirmado que o programa não tem assumido essa formação, um dos coordenadores do PPGE2 é da opinião de que o professor do ensino superior é formado 
nos programas de pós-graduação, por isso ele não pode deixar de ser pesquisador, quer seja mestre ou doutor. Acrescenta que

- [...] a tendência é de que continue sendo formado nos programas o professor do ensino básico e da universidade, mas sem abrir mão da pesquisa [...] Teoricamente os mestrandos vão trabalhar na educação básica, a gente ainda está numa situação de mestres trabalhando no ensino superior por carência [...] A formação de mestre não é para o ensino superior é para a educação básica, isto precisa ser muito focado, a articulação com a educação básica.

A visão de que a pós-graduação seria o melhor lugar para a formação do docente universitário é justificada por um dos coordenadores do PPGE1, pois

- [...] uma formação em nível de pós-graduação nos dá oportunidade de experimentar, para além da pesquisa, um conjunto de outros princípios e orientações, por exemplo, experimentar níveis de autonomia, de autorização desse professor e com mais densidade a questão da originalidade, portanto da autonomia da implicação política no debate com o conhecimento em outros níveis [...] Não vejo formação de professor universitário sem que ele entre no debate ampliado da função da pesquisa na sua formação e no conjunto das formações universitárias.

A ideia de ser a pós-graduação o lugar de formação do professor universitário é reiterada por outro coordenador do PPGE1, 
porque o processo de pesquisar repercute na sua prática docente, em especial no domínio do objeto da pesquisa, o que lhe assegura maior capacidade de problematizar com os seus alunos da graduação:

- [...] uma pessoa que tem uma formação especializada, que conhece profundamente o objeto, em sala, tem uma capacidade de manobra, um jogo de cintura, uma possibilidade de problematização, de avançar certas discussões que são propostas pelos alunos.

Na visão desse participante, a formação para a pesquisa, entendendo que essa se completa com a sua comunicação,

- [...] contribui de maneira sistemática para essa capacidade de organização didática, de fazer uma gestão do trabalho docente, que não é só o conteúdo, ele é só um elemento, muitos outros são necessários para que a gestão do trabalho docente possa ser feita de forma adequada.

No decorrer da entrevista, esse participante arrisca dizer que, dentro do sistema de pós-graduação stricto sensu,

- [...] talvez, as faculdades em educação pudessem cumprir parte desse papel, uma formação básica de nivelamento, dependendo da área que a pessoa vem. Um estudante de pedagogia traz isso mais desenvolvido, mas o estudante de engenharia, não. Não chega nem com o linguajar da educação. Não tenho uma receita, mas acho que seria um lugar para se fazer e hoje não faz ainda. 
A reflexão sobre o lugar dessa formação fez emergir críticas aos programas de pós-graduação stricto sensu. Nesse sentido, um dos participantes do PPGE2 reafirma que os programas de educação não assumem a formação do docente universitário, e a evidência disso é o fato de, na atualidade, o Tirocínio Docente, oferecido no seu programa, ser obrigatório apenas para os bolsistas da CAPES. Se essa restrição se deu em função da reivindicação dos próprios programas, "- [...] então as pessoas podem entrar e sair do mestrado, sair mestres sem saber, entrar numa sala de aula incrível, não é uma contradição? "

A visão epistemológica positivista de parte de muitos professores do programa é apresentada por um dos depoentes do PPGE1 como um obstáculo para que o programa assuma, de forma mais consistente, a formação do docente universitário:

- Nós temos ainda um conjunto de professores do Programa com uma formação objetivista, de ortodoxia positivista, que não dá muita importância ao debate epistemológico, ao debate ético, ao debate político no processo de formação na relação com o saber. É a preocupação apenas com o domínio, com a eficiência e eficácia, [...] fundamentalmente interessa ser um Programa que atende as normas da CAPES.

Considerando que a metodologia do ensino superior deveria estar centrada na investigação, um dos participantes do PPGE2 apresenta crítica à forma como a graduação está estruturada, com um grande número de disciplinas, fragmentadas e ministradas em semestres, o que dificulta o aprofundamento e a elaboração adequada dos conteúdos:

- Mal se inicia o semestre e logo depois o professor tem que dar conta de finalizar 
seu contato com o aluno, dizer se ele está habilitado ou não, inviabiliza a reflexão do conteúdo, isso tudo dificulta a reflexão, fica muito mais fácil para o professor ficar apenas na transmissão e não com a pesquisa como centro. Eu tenho refletido muito como nós (no programa) poderíamos ajudar a graduação. A nossa contribuição tem sido parcial.

Os depoimentos indicam a tendência de conceber a pósgraduação stricto sensu como lugar privilegiado de formação do professor da educação superior, principalmente por considerarem a pesquisa como um elemento fundamental do modelo de docência concebido por eles. Entretanto, na compreensão de lugar assumida neste estudo (CUNHA, 2008), como espaço efetivamente ocupado, preenchido não desordenadamente, mas de acordo com os significados das pessoas que o ocupam e lhe asseguram legitimidade, a pós-graduação stricto sensu, inclusive em educação, não se configura como tal. Não ultrapassa, portanto, a condição de espaço potencial de formação desses professores, tanto do ponto de vista legal quanto na representação dos participantes coordenadores e egressos. Assim, ser espaço mais ou menos reconhecido para a formação em questão não significa que, necessariamente, se constitua em um lugar onde ela aconteça.

Ao lado das críticas, emergem proposições em relação a conteúdos e à metodologia da formação desejável do professor universitário. Um dos coordenadores do PPGE1 considera que “- [...] o profissional deveria entender a universidade onde vai atuar, o que é ser professor universitário", e, na visão de outro, essa formação deveria ter um impacto maior, assumindo a pesquisa e a docência. Seria importante que

- [...] cuidasse da docência como síntese da formação. Uma docência que não fosse um 
Tirocínio apenas centrado no ensino, mas Tirocínio, talvez de um ano, que incluísse a parte da produção do ensino articulada a uma pesquisa, que a maioria das universidades não tem condição de fazer e até os programas. Nosso programa, se desenvolver uma docência articulada com a pesquisa, teria que trazer os estudantes da graduação para o mestrado, trazer como participantes da IC (iniciação científica) [...] como voluntários de pesquisa.

Uma formação na qual o estudante participaria de experiências formativas no contexto da prática, a exemplo da residência médica, é sugerida por um dos membros do PPGE1,

- [...] tanto em instituições carentes para ele aprender a ser criativo nos mecanismos de melhoria da qualidade de ensino e gestão, quanto em instituições de excelência para aprender como ela consegue fazer a excelência, que instrumentos utiliza, ele sairia com ferramentas para seu trabalho.

Essas experiências, na visão do participante, assegurariam um "conhecimento tácito", que seria complementado com um "conhecimento explícito" a partir de

- [...] seminários, preleções orais tradicionais, e aí o uso de estratégias didáticas como metáforas adequadas, como modelos simplificadores e depois a crítica do modelo, se faria o oferecimento de situações desafiadoras, mas não impossíveis para manter a motivação do aluno. Seriam aspectos didáticos importan- 
tes que poderiam ser aprendidos de forma sistemática, porque já há um conhecimento explícito sobre isso. Essa formação poderia se dar ainda, através dos veículos tradicionais antigos de formação, já testados, e que talvez sejam os melhores, bons livros, boas aulas, bons seminários... é a forma de transmissão explícita de conhecimento, bem organizados com as técnicas que pretende ensinar, boa capacidade comunicativa, organização visual adequada, boa organização do espaço.

Esse depoimento, entre outros aspectos, parece sinalizar a lógica tecnicista e voltada para o domínio de conteúdos da concepção da formação docente, que, ao que tudo indica, prevalece na universidade. Assim, a formação para a docência fica entre a inexistência, subsumida pela formação para a pesquisa, e a sua redução a estratégias e técnicas.

O fato de introduzir-se, na graduação, a iniciação científica "[...] como método, e não como programa de bolsa [...]" é percebido por um dos coordenadores do PPGE2 como o ponto de partida da formação do professor universitário:

- Todos os graduandos iriam passar por uma formação compreensiva na qual o mais importante é ler, investigar e escrever bastante, porque a gente tem a tradição de ouvir, de ouvir o que o professor diz. No entanto o mais importante se a gente quer formar em ensino superior é ler e escrever bastante à luz das suas ideias, da sua visão de mundo, do que leu, a erudição ajudando na sua reflexão e isto é a verdadeira metodologia do ensino superior. 


\section{A avaliação da CAPES frente à dimensão pedagógica como função da pós-graduação}

Os coordenadores registraram, de forma unânime, que a CAPES não contempla, no processo de avaliação dos programas de pós-graduação, a dimensão pedagógica da formação dos docentes, apesar dessa instituição, como ilustra um dos coordenadores do PPGE2, prever

- Várias modalidades de inserção do professor (da pós-graduação) na graduação, através do ensino, da orientação de monografia, da realização de trabalhos técnicos, do ponto de vista quantitativo, não avalia o como faz em nenhum aspecto. É uma restrição do conceito de avaliação na própria área de educação. Vai ter que romper com isso, porque a demanda pela avaliação qualitativa é muito pertinente, há um imperativo maior no sentido de valorizar as referências das ciências duras, mas a área de humanas briga muito por isso.

Um dos membros do PPGE1 registra que, para a CAPES incluir a dimensão pedagógica na avaliação dos programas, seria necessário alterar o seu papel, passando a assumir a formação numa perspectiva mais ampla, e não voltada, apenas, para a pesquisa:

- Seria desejável uma formação profissional em que a qualidade do ensino seja mais relevante, em todos os seus aspectos, não só de competência do conteúdo. Aí não dá para fugir da discussão pedagógica. Não sei se é a CAPES que tem que fazer o encaminhamento, se pode ser feita de forma quantitativa, como a CAPES avalia hoje. Temos que encontrar estratégias mais corporais, mais quentes, 
mais locais, com os pares, com professores, os alunos, com todos os envolvidos, um processo mais negociado. Ela (avaliação) pode ter níveis, mas o nível mais fundamental para que ela seja efetiva tem que ser o nível da sua execução.

Ainda sobre a mesma questão, opina outro representante do PPGE1:

- A CAPES é importante, mas é uma agência de avaliação, não é um programa de pósgraduação. Os programas de pós-graduação têm uma história, têm um contexto, têm uma identidade, são lugares de formação. Uma agência de avaliação tem que ser vista como uma agência de avaliação, com a importância que tem, e não como espelho de um programa como tem que ser. Há uma confusão [...] mas tem uma intenção e uma filosofia por trás disso, não é ingênuo.

A tendência dos programas de se tornarem cópia das recomendações da CAPES para obter boa classificação no sistema de pós-graduação, na visão desse depoente, é preocupante, pois coloca em crise a crítica como um dos pilares da ideia de universidade. Para ele,

- [...] apenas vamos atender as demandas da agência de avaliação para que a gente se dê bem ao final de algumas avaliações. Eu considero essa preocupação pertinente, mas não como uma ordem para ser atendida de maneira absoluta até porque agência de avaliação é agência de avaliação. 
Frente aos dados colhidos junto aos interlocutores do estudo, é possível afirmar que a representação de docência universitária, que parece unificar os participantes, vincula o ensino à pesquisa, como meio de formar os docentes na perspectiva da autonomia. A visão da docência, como portadora de saberes do "campo educacional", se expressa mediante formulações genéricas, a saber, "transposição didática", "capacidade didática", ou em defesa da importância desses saberes sem que sejam exemplificados ou nomeados, sinalizando uma frágil reflexão coletiva sobre eles. Em diversos momentos, os saberes do campo pedagógico foram reduzidos ao domínio de estratégias e técnicas.

Considerando a importância da vinculação do ensino à pesquisa, os participantes concluem que a pós-graduação stricto sensu deveria ser o lugar privilegiado para a formação do docente universitário, possibilitando-lhe maior domínio dos conteúdos estudados e o desenvolvimento da capacidade de problematização e de argumentação, em consonância com a concepção de docência centrada na pesquisa.

A maioria reconhece, entretanto, que esses programas têm como foco a formação do pesquisador e que, efetivamente, eles não têm assumido a formação para a docência, ou têm feito isso de forma muito limitada, graças à iniciativa de alguns professores ou o desenvolvimento de atividades, como o Tirocínio Docente, mesmo que seja mais por determinação da CAPES. Essa determinação é a única que sugere uma aproximação dessa agência com a formação do docente universitário.

Enfim, os depoimentos permitem concluir que os programas de pós-graduação em educação, pelo menos aqueles que foram objeto deste estudo, parecem perder de vista a especificidade do campo da educação, no que tange à formação do docente da educação superior. A assunção da formação de pesquisadores, como principal objetivo da pós-graduação em educação na busca de seu reconhecimento, se verificou, tal qual os demais programas, 
concomitantemente, com o silenciamento sobre a formação pedagógica e didática de novas gerações de mestres e doutores.

A procura desse espaço de formação por docentes de áreas distintas do campo da educação poderia estar servindo para instigar os PPGs em Educação a refletir sobre as possibilidades e desafios no campo da formação do docente universitário. Nessa direção, este estudo pretende aliar-se aos estímulos para refletir sobre os saberes profissionais dos docentes da educação superior e o papel dos programas de pós-graduação em educação na formação desses profissionais. 



\section{Capítulo 6}





\section{Reflexões e dilemas sobre a formação do docente da educação superior}

O estudo empreendido nos permitiu concluir que a docência universitária, na representação dos interlocutores, ainda é um campo de conhecimento cuja complexidade e especificidade são pouco reconhecidas. $\mathrm{O}$ ensino não se instala como uma atividade que possui e exige saberes próprios, porquanto fica subsumido à pesquisa. Os coordenadores dos programas reconhecem a competência de pesquisar como principal atributo do docente universitário, por considerarem que a pesquisa é um meio fundamental para desenvolver, nos estudantes, o questionamento, a reflexão crítica e a problematização na perspectiva da formação da autonomia. Mas focaram, com pouca ênfase, as especificidades da docência, incluindo o como desenvolver as habilidades investigativas em classes com os estudantes.

Assim, a competência para realizar o ensino com pesquisa na universidade, para a maioria dos coordenadores, parece ser uma decorrência natural do ensino para pesquisa (PAOLI, 1988), ou seja, da formação do docente como pesquisador. Essa compreensão é assumida também, embora com menos ênfase, pelos egressos 
dos Programas quando valorizam as aprendizagens da pesquisa que adquiriram no percurso da pós-graduação. Salientaram a repercussão dessa aprendizagem na sua forma de ensinar, traduzida na capacidade de provocar a reflexão e o questionamento do estudante, sem fazer referência ao aprendizado de ensinar com pesquisa na sua sala de aula da graduação. Certamente essa percepção decorre da ênfase dada à pesquisa como central na modalidade de formação pós-graduada e ao silenciamento sobre os saberes da docência.

Conforme Paoli (1988), o ensino com pesquisa e o ensino para pesquisa, embora tenham elementos comuns, não são a mesma coisa. O ensino com pesquisa constitui-se em uma proposta de trabalho educativo que toma os pressupostos investigativos como base do ensinar e do aprender. Contrapõe-se ao ensino livresco, baseado na transmissão de verdades estabelecidas. Possibilita a construção de atitudes e práticas científicas, a valorização da dúvida e da crítica, o desenvolvimento da capacidade de discernimento, da percepção aguçada para lidar com o conhecimento e da habilidade de expressão, argumentação e de escrita. Procura formar o sujeito cognoscente, capaz de interpretar e intervir no seu campo profissional de forma efetiva e com autonomia intelectual.

O ensino para a pesquisa, desenvolvido nos cursos de pósgraduação stricto sensu, visa à produção de um conhecimento ou interpretação original, envolve um razoável domínio das pesquisas já desenvolvidas acerca do objeto em estudo, bem como das teorias e modelos concernentes aos conceitos que lhe são inerentes. Pressupõe rigor no levantamento, organização e interpretação dos dados, em consonância com os critérios das diferentes comunidades científicas. Visa formar o pesquisador. 
A visão de que a pesquisa tem, necessariamente, uma repercussão positiva na docência, conforme indicam diversos estudos (HEALEY, 2008; HUGHES, 2008; SCOTT, 2008), é bastante generalizada, a despeito da inexistência de dados empíricos que a confirmem. Ao que tudo indica, a competência para pesquisar não se traduz de forma espontânea e automática no ensino, pois, além de essas atividades dependerem de um conjunto de circunstâncias e fatores, como incentivos institucionais, condições de tempo, espaço, recursos, equipamentos e, ainda, das idiossincrasias dos profissionais que desenvolvem essas atividades (PAOLI, 1988), elas possuem naturezas distintas. Em geral,

[...] o objetivo prioritário da investigação é formular perguntas e gerar novos conhecimentos. Enquanto, em contrapartida, os estudantes dedicam grande parte de seu tempo a responder perguntas e consolidar conhecimentos aceitos. (SHORE et al., 1990 apud HUGHES, 2008, p. 32, tradução nossa) ${ }^{8}$

Uma relação consistente, eficaz e direcionada para a formação de profissionais investigativos, críticos, transformadores, entre as atividades de ensino e pesquisa, pressupõe um amplo e profundo debate acerca da concepção de ensino predominante na universidade, que é aquela baseada na transmissão disciplinar e fragmentada de conhecimentos consolidados. A aprendizagem do estudante, entendida como construção do saber que lhe é próprio, se constitui no elo capaz de tornar mais natural essa relação e se estabelece como uma ponte indispensável para a implementação do ensino com pesquisa na graduação. Corroborando com essa compreensão, percebe-se a posição de muitos autores que afirmam que

[...] a docência e a investigação apresentam uma correlação na medida em que estão relacionadas,

\footnotetext{
${ }^{8}[$ [... el objetivo prioritario de la investigación es formular preguntas y generar nuevos conocimientos. En cambio, los estudiantes dedican gran parte de su tiempo a responder preguntas y consolidar conocimientos aceptados.
} 
isto é, quando o que se relaciona são dois aspectos da mesma atividade: a aprendizagem.(BREW ; BOUD, 1995 apud HUGHES, 2008, p. 33, tradução nossa) ${ }^{9}$

Para viabilizar uma relação consistente entre ensino e pesquisa, é preciso que o ponto de partida seja a compreensão da docência e dos saberes específicos indispensáveis para gerar aprendizagens baseadas na participação ativa de todos os estudantes no ensino com pesquisa. Se as atividades de iniciação científica são boas experiências para alguns estudantes, a relação do ensino de graduação com a pesquisa não pode a ela se reduzir. Todos os alunos merecem um percurso de formação no qual a pesquisa seja o fio condutor do processo educativo.

Todavia, a subsunção da docência à pesquisa, identificada neste estudo nos depoimentos da maioria dos participantes e nos documentos dos programas, não pode ser vista de forma isolada. Ela expressa uma concepção de conhecimento usual historicamente construída e institucionalizada. Há, também, resquícios da centralização e autoritarismo presentes nos Pareceres 977/65 e 77/69 e, na continuidade, nos Planos Nacionais de Pós-Graduação, que estabelecem as metas e prioridades para cada período, em consonância com esses pareceres. A despeito da consolidação do sistema de pós-graduação que esses instrumentos legais e as políticas e investimentos deles decorrentes possibilitaram, cabe destacar que eles pouco contribuíram para a valorização da docência como um campo de saber universitário. Muitas vezes concorreram para a separação organizacional entre produção e disseminação do conhecimento na universidade, em razão da caracterização da pós-graduação como espaço de produção e a graduação como consumo de conhecimento (PAOLI, 1988). Em decorrência, houve

${ }^{9}$ [...] la docencia y la investigación presentan una correlación en la medida en que están relacionadas, esto es, quando lo que se relaciona son dos aspectos de la misma actividad: el aprendizaje. 
uma supervalorização da pesquisa e uma subestimação da complexidade e da especificidade da docência.

Os coordenadores de programas se expressaram com formulações genéricas acerca dos saberes próprios do "campo educacional". Todos assumem como indispensáveis, mas não conseguem especificá-los, nomeá-los; sinalizam a tendência de concentrarem sua atenção na pós-graduação, apesar de atuarem, também, na graduação, cujos perfis e demandas dos estudantes são distintos. Os egressos, por sua vez, quando estimulados a se expressarem, avançaram mais, identificando diversos elementos que configuram os saberes específicos da docência, provavelmente porque a sua condição de professores da graduação coloca desafios concretos que lhes permitem reconhecer algumas lacunas e necessidades que remetem a saberes do "campo educacional".

A pouca apropriação e visibilidade dos saberes específicos da docência, evidenciada nos depoimentos dos participantes, revela a ausência de reflexão coletiva sobre a docência na universidade, provavelmente em função da crença construída na longa trajetória do ensino universitário tradicional, que parece ainda predominar e tem suscitado a realização de diversos fóruns nacionais e mundiais sobre a educação superior, de que a competência científica e a capacidade de comunicar bastam para ser professor. Entretanto, a complexidade da docência se impõe quando esse ensino tradicional não responde aos desafios colocados na contemporaneidade e, como nos lembra Reimão (2001), a passagem do modelo pedagógico magistro-centrado para o modelo sócio-centrado coloca novas exigências para o docente universitário como

[...] construir grupos, animar a sua dinâmica, prever actividades variadas, visando os objectivos da aprendizagem. Porque o saber não se transmite, mas constrói-se, a propósito de problemas, activamente, dialecticamente [...] (REIMÃO, 2001, p. 23) 
Reconhecer essa complexidade e a existência de saberes próprios à docência universitária remete à questão da profissinalização docente. A docência, em especial a exercida na escola básica, tem sido considerada como semiprofissão ou como ofício, de acordo com Gimeno Sacristan (1995), em função do condicionamento que os sistemas educativos e as organizações escolares a submetem. A prática do professor depende das condições do seu espaço de trabalho e das coordenadas político-administrativas que regulam o sistema de ensino. Sua margem de autonomia depende, em grande medida, das relações que foram estabelecidas historicamente entre a burocracia que governa a educação e os professores. Desse modo, a autonomia exprime-se dentro de regras bastante definidas, que levam as ações profissionais a uma acomodação às situações concretas.

Os professores universitários têm se colocado ao largo desse debate sobre a profissionalização da docência porque nem mesmo se reconhecem como professores no contexto das relações do trabalho, pois, como sinalizam Pimenta e Anastasiou (2002), em geral, continuam a se identificar como profissionais dos seus campos específicos, como médicos, engenheiros, enfermeiros, contadores etc., mesmo quando a sua atividade principal é o ensino. Tal situação revela o desprestígio da docência e a ausência de conhecimentos profissionais para o seu exercício e concorre para a maior fragilização da sua condição como profissão.

A profissão, segundo Popkewitz (1992 apud VEIGA et al., 2005), se diferencia qualitativamente do ofício, ocupação ou emprego. No dizer de Bourdoncle (1991, p. 78)

[...] as profissões se distinguem dos ofícios pelo fato de serem professadas, isto é, aprendidas a partir de declarações públicas, de racionalizações discursivas e não por simples aprendizagem imitativa. 
O termo profissão se refere, portanto, à existência de uma base de saber que ganha autonomia em relação à prática e se desenvolve pela pesquisa sobre a prática e pela própria prática, cujos saberes e competências são construídos não por imitação, mas mediante uma longa formação universitária, em geral de natureza científica. Essa formação, como sinaliza Tardif (2002a), deve ser voltada para a reflexão, o discernimento e a compreensão de situações problemáticas do contexto da prática profissional e para a definição de objetivos pertinentes à situação e a identificação dos meios adequados para atingi-lo.

No caso do docente universitário, a sua formação tem sido preponderantemente intuitiva e imitativa. Conforme Benedito e outros (1995, p. 120, tradução nossa)

[...] o professor universitário aprende a sê-lo mediante um processo de socialização em parte intuitivo, autodidata ou, o que é pior, seguindo a rotina dos 'mais experientes'. Isto se explica, sem dúvida, devido à inexistência de uma formação específica como professor universitário. ${ }^{10}$

Complementa o autor que, nessa construção pessoal, contribuem, ainda, com maior ou menor destaque, as marcas das suas experiências na condição de estudante, o modelo predominante de docência no sistema universitário, a reação dos estudantes às suas posturas e práticas educativas e possíveis trocas com os colegas. Mesmo reconhecendo esses campos culturais como importantes para a docência, a falta de uma formação estruturada dificulta a ação reflexiva, fazendo da docência uma atividade naturalizada, como se não exigisse uma base teórica e conceitual para seu exercício.

\footnotetext{
${ }^{10}[. .$.$] el profesor universitário aprende a serlo mediante un proceso de socialización en parte intuitivo,$ autodidacta o, lo que es peor, siguiendo la rutina de 'los mayores'. Se debe, sin duda, a la inexistencia de una formación específica como profesor universitário.
} 
A formação dos professores universitários é uma questão secundária e sem visibilidade nos programas de pós-graduação, inclusive os da área da educação, como revela este estudo. Com efeito, todos os coordenadores reconheceram que os programas concentram sua atenção na formação do pesquisador e que, efetivamente, não têm assumido a formação para a docência, ou têm feito isso de forma muito limitada, graças à iniciativa de alguns professores, ou desenvolvido atividades isoladas em obediência à determinação da CAPES, e não como fruto de uma intencionalidade comprometida com a formação do docente universitário. Os egressos também afirmaram que a formação para a docência não foi intencionalmente assumida pelos programas, e alguns acrescentam que as práticas educativas oportunizadas e a atuação de alguns professores tampouco serviram de exemplo para a docência, o que causou estranheza considerando a natureza da área.

Fica evidente a falta de uma ambiência que valorize a formação pedagógica e que oportunize, institucionalmente, uma reflexão coletiva sobre os pressupostos teóricos, epistemológicos, políticos, pedagógicos, metodológicos da prática docente. O que equivale a dizer que essa formação, efetivamente, não tem se concretizado como uma política institucional dos programas.

Essa realidade não é invenção desses programas, ela é a reprodução de uma lógica nacional estabelecida para os cursos de pós-graduação stricto sensu, que, considerando o objeto deste estudo, tem como traço característico a centralidade da formação do pesquisador. No caso dos programas de pós-graduação em educação, assumir a formação de pesquisadores como principal objetivo, conforme enfatizam Ramalho e Madeira (2005), se verificou, concomitantemente, com o descuido da formação pedagógica e didática de novas gerações de mestres e doutores.

Conformados a essa lógica, os programas tendem a concentrar suas ações a fim de atender as exigências dos processos avaliativos da CAPES, esvaziando as energias que poderiam ser investidas 
em iniciativas e construções sintonizadas com o contexto político, social, cultural no qual estão inseridos. Tal situação revela o peso das políticas que atrelam a proposta de formação a políticas de fomento, como registrou Frigotto (apud FÁVERO, 1993), exigindo "o cumprimento exato das normas estabelecidas", padronizadas, em geral mais afeitas às características dos programas das áreas de exatas e naturais; por outro lado, revela também a ausência de um amplo debate por parte dos programas, que, diante da situação de competição por recursos, se veem premidos a cumprir as exigências, mais do que a confrontá-las. Esses aspectos, portanto, compõem o cenário que permite uma compreensão dos limites e desafios dos programas referidos nos depoimentos dos egressos e coordenadores participantes do estudo.

Interessante ressaltar que, a despeito do estranhamento inicial de muitos participantes acerca da temática da formação do docente universitário, todos se sentiram mobilizados a refletir sobre isso e, num processo de tateamento, típico de um contexto de incertezas e de pouca aproximação com a temática, tendem a considerar que a pós-graduação stricto sensu seria o lugar mais adequado para a formação desse professor. Possibilitar-lhe-ia um maior domínio dos conteúdos estudados e o desenvolvimento da capacidade de problematização e de argumentação. Os egressos também afirmaram a necessidade desse lugar, formulando, inclusive, sugestões de conteúdos e metodologia com base na reflexão das lacunas vivenciadas no sentido da formação para a docência.

O que se verifica é que, a despeito de não ser uma questão que estava conscientemente posta pelos participantes, os desafios da formação dos docentes universitários são identificados e sentidos. O estudo contribuiu para fazê-los vir à tona e evidenciar a necessidade de buscar a legitimidade da docência universitária e de sua formação.

Esse processo de afirmação da legitimidade da docência universitária e de sua formação poderia ser estimulado pelas instâncias governamentais responsáveis pela educação superior, 
inclusive pela pós-graduação, mas seria desejável que partisse da iniciativa dos professores dos programas de pós-graduação, em especial aqueles da área de educação, em articulação com os professores e coordenadores dos departamentos a que pertencem.

Nessa perspectiva, apresentamos algumas proposições, que se delinearam com este estudo, a fim de fomentar a discussão com vistas à busca da legitimidade da formação e da docência universitária:

- $\quad$ Estímulo à criação, nos programas de pós-graduação, de linhas de pesquisa voltadas para a reflexão sobre os saberes e práticas da docência universitária nos diversos campos, em especial as que analisam experiências positivas de ensinar e aprender na universidade, como metodologia de construção de conhecimentos.

- Inclusão, nas propostas curriculares dos programas de pós-graduação, de conteúdos que possibilitem a construção coletiva da profissionalidade do docente da educação superior. Nesse sentido, emergem como conteúdos fundamentais: a temática dos modelos de universidade e a relação com as práticas dos docentes; os paradigmas de ciência e a sua expressão nas posturas e práticas docentes; a questão das profissões e os desafios da formação de profissionais para os docentes na atualidade; fundamentações epistemológicas do ensino; a natureza da aprendizagem e suas implicações na atividade docente, em especial, por se tratar de estudantes adultos; as estratégias de ensino-aprendizagem; a questão do ensino com pesquisa; a natureza social e intersubjetiva do trabalho docente. O contexto grupal do processo ensino-aprendizagem e suas implicações para o docente universitário: o grupo como dispositivo de aprendizagem; a ética na docência universitária;

- $\quad$ Ressignificação do sentido e do formato de experiências de formação, como o Estágio e o Tirocínio Docente e a sua 
inserção num contexto mais amplo de reflexão sobre a docência universitária.

- Desenvolvimento de estudos e pesquisas sobre os estudantes, sua cultura e estilos de vida e de aprendizagem, códigos culturais e expectativas.

- $\quad$ Adoção, pelas universidades, de mecanismos de valorização da formação pedagógica e da melhoria das práticas educativas dos seus professores, que sejam contemplados no processo de avaliação e de progressão da carreira, hoje restrita a titulação e produção relacionada à pesquisa.

- $\quad$ Criação de espaços e fóruns de compartilhamentos das experiências inovadoras de ensino, geradoras de aprendizagens desenvolvidas pelos docentes na graduação e na pós-graduação, envolvendo os docentes na identificação de situações-problemas relativas ao ensino e aprendizagem na universidade.

- $\quad$ Publicação de estudos que contemplem reflexões sobre as práticas de ensinar e aprender na universidade.

- Estímulo ao engajamento dos professores nos grupos de pesquisa existentes na pós-graduação e à participação em estudos e pesquisas voltados para a compreensão das suas próprias práticas docentes.

- $\quad$ Fomento ao debate sobre a importância do aperfeiçoamento pedagógico dos docentes.

- $\quad$ Revisão das formas de recrutamento e progressão na carreira do professor universitário, ressaltando a importância dos saberes da docência. 
Essas proposições certamente não esgotam o campo de reflexão e estudo, mas podem ajudar a orientar o debate no contexto das políticas públicas e institucionais, em especial no âmbito da pós-graduação stricto sensu, objeto deste estudo. Procuram, especialmente, um diálogo com os programas de pós-graduação em educação, estimulando-os a assumir a liderança no processo de valorização de um campo científico e profissional em torno dos saberes da docência. Provocam-os a se constituírem em um lugar de formação do docente da educação superior, entendendo esse termo na luta concorrencial de ocupação dos espaços acadêmicos, com propriedade e determinação. 


\section{Referências}

ALTET, Marguerite. As competências do professor profissional: entre conhecimentos, esquemas de ação e adaptação, saber analisar. In: PAQUAY, Léopold et al. (Org.). Formando professores profissionais: quais estratégias? Quais competências? Tradução Fátima Murad; Eunice Gruman. Porto Alegre: Artmed, 2001.

AMBRÓSIO, Teresa. Conhecimento pedagógico e competências dos professores/ investigadores universitários. In: REIMÃO, C. (Coord.). A Formação Pedagógica dos Professores do Ensino Superior. Lisboa: Colibri, 2001.

BENEDITO, V.; PAIVA, V.S.F.; FERRER, V. La formación universitária a debate. Barcelona: Universitat de Barcelona, 1995.

BIANCHETTI, Lucídio; Marques ,Juracy C. Primórdios e expansão da pós-graduação stricto sensu em educação na região sul, Revista Brasileira de Educação, Rio de Janeiro, n. 30, p 151-161, set. /dez. 2005.

BOURDONCLE, Raymond. La profissionnalisation des enseignants: analyses sociologiques anglaises et américaines. Revue Française de Pédagogie, n. 94, p. 73-92, janv./mars. 1991.

BRASIL. Ministério da Educação. Parecer 977/65. Documenta, Brasília: MEC/CFE, n. 44, p. 67-86, dez. 1965.

BRASIL. Ministério da Educação. Parecer 77/69. Documenta, Brasília: MEC/CFE, n. 98, p. 128-132, dez. 1969.

BRASIL. Ministério da Educação. I Plano Nacional de Pós-Graduação. Brasília: MEC/CAPES, 1974.

BRASIL. Ministério da Educação. II Plano Nacional de Pós-Graduação 1982-1985. Brasília: MEC/CAPES, 1982.

BRASIL. Ministério da Educação. III Plano Nacional de PósGraduação1986-1989. Brasília: MEC/CAPES, 1986.

BRASIL. Ministério da Educação. Lei n. 9.394, de 20 de dezembro de 1996. Estabelece as Diretrizes e Bases da Educação Nacional. Brasília, DF: MEC, 1996.

BRASIL. Ministério da Educação. V Plano Nacional de Pós-Graduação (2005-2010). Brasília: MEC \CAPES, 2004. Disponível em: < http: // 
www.capes.gov.br/sobre-a-capes/plano-nacional-de-pos-graduacao > . Acesso em : 05 jan. 2009.

CHAMLIAN, Helena Coharik. Docência na universidade: professores inovadores na USP. Cadernos de pesquisa, São Paulo, n. 118, mar. 2003.

COMENIUS. Didática Magna. Tradução Ivone Castilho Benedetti. São Paulo: Martins Fontes, 1997.

CUNHA, Maria Isabel da. A docência como ação complexa: o papel da didática na formação dos professores. In: ROMANOWSKI, Joana; MARTINS, Pura Lucia; JUNQUEIRA, Sérgio. (Org.). Conhecimento local e conhecimento universal: pesquisa, didática e ação docente. Curitiba: Champagnat, 2004. v. 1. p. 31-42.

. Trajetórias e lugares de formação da docência universitária: da perspectiva individual ao espaço institucional a ser realizado. São Leopoldo: Unisinos, 2006. Projeto de pesquisa. PPGEdu

. Os conceitos de espaço, lugar e território nos processos analíticos da formação dos docentes universitários. Revista Educação Unisinos, v. 12, n. 3, set. /dez. 2008.

DESAULNIERS, Marie-Paule et al. Le profissionnalisme vers un renouvellement de l'identité professionnelle. In: Georges A. Legault (Dir.). Crise d'identité professionnelle et profissionnalisme. Quebec: Presses de l’Université Du Québec, 2003. p. 183-226.

DIAS, José Ribeiro. A Formação Pedagógica dos Professores do Ensino Superior. In: REIMÃO C. (Coord.). A Formação Pedagógica dos Professores do Ensino Superior. Lisboa: Colibri, 2001.

FÁVERO, Osmar. A trajetória da Pós-Graduação em Educação no âmbito institucional. In: Associação Nacional de Pós-Graduação e Pesquisa em Educação. Avaliação e perspectivas na área de educação 198291. Porto Alegre: Anped, 1993.

GIMENO SACRISTÁN, J. Consciência e acção sobre a prática como libertação profissional dos professores. In: NÓVOA, António. Profissão professor. Porto: Porto, 1995.

GROS SALVAT, Begoña; ROMAÑÁ BLAY, Teresa. Ser professor: palabras sobre la docencia universitária. Barcelona: Octaedro, 2004.

HEALEY, Mick. Vínculos entre docência e investigación: reflexión em torno a los espacios disciplinares y el papel del aprendizaje basado en 
la indagación. In: BARNETT, Ronald (Ed.). Para Una transformación de la universidad: nuevas relaciones entre investigación, saber y docencia. Barcelona: Octaedro, 2008. p. 93-137.

HUGHES, Mark. Los mitos en torno a las relaciones entre investigación y docencia en las universidads. In: BARNETT, Ronald (Ed.). Para Una transformación de la universidad: nuevas relaciones entre investigación, saber y docencia. Barcelona: Octaedro, 2008.

LUCARELLI, Elisa. Paradojas de um rol: el asesor pedagógico en la universidad. In: LUCARELLI, E (Org.). El asesor pedagógico en la universidad: de la teoria pedagógica a la práctica en la formación. Buenos Aires: Paidós, 2004.

LUDKE, Menga; ANDRÉ, Marli E. D. A. Pesquisa em educação: abordagens qualitativas. São Paulo: EPU, 1986.

. Influências cruzadas na constituição e na expansão do sistema de pós-graduação stricto sensu em educação no Brasil. Revista Brasileira de Educação, Rio de Janeiro, n. 30, set./dez. 2005.

MARCELO GARCIA, Carlos. Formação de Professores: para uma mudança educativa. Portugal: Porto, 1999.

MINAYO, Maria Cecília de Souza. Pesquisa social: teoria, método e criatividade. Petrópolis, SP: Vozes, 1994.

NAIDOO, Rajani. La universidad y el mercado: distorsiones en la investigación y la docencia. In: BARNETT, Ronald (Ed.). Para una transformación de la universidad: nuevas relaciones entre investigación, saber y docencia. Barcelona: Octaedro, 2008. p. 45-56.

PAOLI, Niuvenius J. O princípio da indissociabilidade do ensino e da pesquisa: elementos para uma discussão. Cadernos CEDES, São Paulo, n. 22, 1988. Número especial dedicado ao tema: Educação superior: autonomia, pesquisa, extensão, ensino e qualidade.

PIMENTA, Selma; ANASTASIOU, Lea. Docência no Ensino Superior. São Paulo: Cortez , 2002. v. 1.

POURTOIS, J-P. ; Desmet, H. Épistémologie et instrumentation en sciences humaines. Bruxelles: Pierre Mardaga, 1988.

RAMALHO, Betania Leite; MADEIRA, Vicente de Paulo Carvalho. A pós-graduação em educação no Norte e Nordeste: desafios, avanços e perspectivas. Revista Brasileira de Educação, Rio de Janeiro, n. 30, set./ dez. 2005. 
REIMÃO, Cassiano. Apresentação do colóquio. In: REIMÃO, Cassiano (Org.). A formação pedagógica dos professores do ensino superior. Lisboa: Colibri, 2001. p. 19-25.

RODRIGUES, Maria Ângela Perpétua. Análise de práticas e de necessidades de formação. Lisboa: Colibri, 2006.

SACRISTÁN, J. G. Consciência e acção sobre a prática como libertação profissional dos professores. In: NÓVOA, Antônio. (Org.). Profissão professor. Porto: Porto, 1995.

SANTOS, Boaventura de Sousa. Um discurso sobre as ciências. São Paulo: Cortez, 2005a.

- A Universidade no século XXI: para uma reforma democrática e emancipatória da Universidade. 2. ed. São Paulo: Cortez, 2005b.

SCOTT, Peter. ¿Divergencia ou convergencia? Las relaciones entre docência e investigación en la educación superior de masas. In:

BARNETT, Ronald (Org.). Para Una transformación de la universidad: nuevas relaciones entre investigación, saber y docencia. Barcelona: Octaedro, 2008. p. 75-91.

SEVERINO, Antonio J. Pressupostos filosóficos da formação e da prática do educador. Cadernos de Educação, Pelotas, v. 15, n. 27, p.37-54, jul./dez. 2006.

SOARES, Sandra Regina. Cidadania e relação com o saber no currículo de formação de professor: desvelando sentidos da prática educativa. Revista Educação Unisinos, v. 12, n. 3, set./dez. 2008.

SOUTO DE ASCH, Marta. Hacia una didáctica de lo grupal. Buenos Aires: Mino y Dávila , 2007.

TARDIF, Maurice. Saberes docentes e formação profissional. 5.ed. Petrópolis: Vozes, 2002a.

. Lugar e sentido dos conhecimentos universitários na formação dos profissionais do ensino. In: GARRIDO, Susane Lopes; CUNHA, Maria Isabel da; MARTINI, Jussara Gue. (Org.). Os rumos da educação superior. São Leopoldo: Unisinos, 2002b. p.75-112.

VEIGA, Ilma Passos de Alencastro; ARAUJO, José Carlos Souza; KAPUZINIAK, Célia. Docência: uma construção ético-profissional. Campinas, SP: Papirus, 2005.

VIEIRA, Flávia. Transformar a Pedagogia na Universidade? Currículo sem Fronteiras, v. 5, n.1, p.10-27, jan./jul. 2005. 



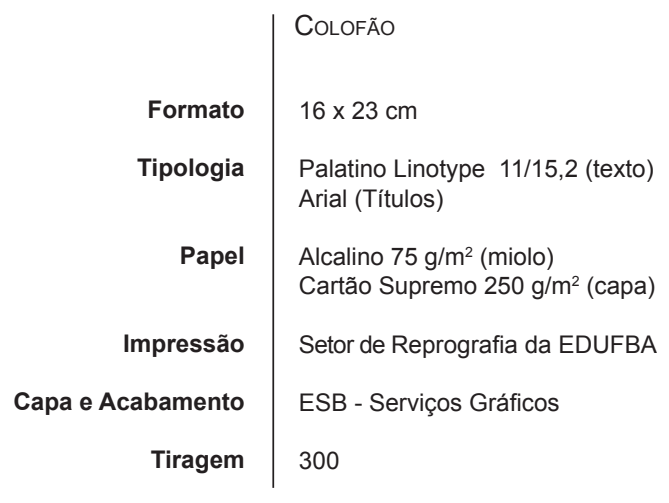

